\title{
Exploration for deep geothermal reservoirs in Luxembourg and the surroundings - perspectives of geothermal energy use
}

Tom Schintgen

\section{Correspondence:} tom.schintgen@gfz-potsdam.de Helmholtz Centre Potsdam - GFZ German Research Centre for Geosciences, Telegrafenberg, 14473 Potsdam, Germany

\begin{abstract}
Background: The aim of this paper is to combine different types of information necessary for a first rather qualitative assessment of deep geothermal reservoirs in the region of Luxembourg. Within the geological framework, the study area encompasses Luxembourg and the surrounding areas of Belgium, Germany, and France. On the one hand, the focus is laid on low-enthalpy hydrothermal reservoirs in Mesozoic aquifers in the Trier-Luxembourg Embayment. On the other hand, petrothermal reservoirs in the Devonian basement of the Ardennes and Eifel regions are considered for exploitation by Enhanced/Engineered Geothermal Systems (EGS).
\end{abstract}

Methods: For geothermal exploration and exploitation purposes, geological, thermal, hydrogeological and structural data are necessary.

Results: Among the Mesozoic aquifers, the Buntsandstein aquifer characterized by temperatures of up to $50^{\circ} \mathrm{C}$ is a suitable hydrothermal reservoir that could be exploited by means of heat pumps or provide direct heat for various applications. The most promising area is the zone of the SE-Luxembourg Graben. The aquifer is the warmest underneath the upper Alzette valley and the limestone plateau in Lorraine, where the Buntsandstein aquifer lies below a thick Mesozoic cover. At the base of an inferred Rotliegend graben in the same area, temperatures of up to $75^{\circ} \mathrm{C}$ are expected. However, geological and hydraulic conditions are uncertain. In the Lower Devonian basement, thick sandstone-/quartzite-rich formations with temperatures $>90^{\circ} \mathrm{C}$ are expected at depths $>3.5 \mathrm{~km}$ and likely offer the possibility of direct heat use. The setting of the Südeifel (South Eifel) region, including the Müllerthal region near Echternach, as a tectonically active zone may offer the possibility of deep hydrothermal reservoirs in the fractured Lower Devonian basement. Based on recent data on the structure of the Trier-Luxembourg Basin, the new concept presents the Müllerthal-Südeifel Depression as a Cenozoic tectonic structure that is still mobile and relevant for geothermal exploration.

Conslusion: Beyond direct use of geothermal heat, the expected modest temperatures at $5 \mathrm{~km}$ depth (about $120^{\circ} \mathrm{C}$ ) and increased permeability by EGS in the quartzite-rich Lochkovian could prospectively enable combined geothermal heat production and power generation in Luxembourg and the western realm of the Eifel region.

Keywords: Geothermal energy; Eifel Depression; South Eifel; Buntsandstein; Lower Devonian; Hydrothermal systems; Petrothermal systems; Enhanced Geothermal Systems; Trier-Luxembourg Embayment

\section{Springer}

(c) 2015 Schintgen. This is an Open Access article distributed under the terms of the Creative Commons Attribution License (http:// creativecommons.org/licenses/by/4.0), which permits unrestricted use, distribution, and reproduction in any medium, provided the original work is properly credited. 


\section{Background}

\section{Status quo of geothermal energy use}

Geothermal energy currently represents a very low percentage of the national energy mix in Luxembourg, and geothermal resources in the subsurface of Luxembourg and the surrounding areas are barely known. Its use is mainly restricted to heat pump systems (Biermayr et al. 2007; Häfner et al. 2007). A remarkable exception is hydrothermal water tapped since 1846 by means of deep wells in Mondorf (southeastern Luxembourg) and used for the local spa (Mf in Figure 1a; Bintz 2000; Lucius 1923, 1948, 1949; Leichtle 1980). The water originates from the Buntsandstein aquifer at depths between 600 and $700 \mathrm{~m}$ with temperatures in the range of $25^{\circ} \mathrm{C}$ to $28^{\circ} \mathrm{C}$. Similarly, the French site of Amnéville (Am) exploits for the local spa warm water $\left(36^{\circ} \mathrm{C}\right.$ to $42^{\circ} \mathrm{C}$ ) since 1979 by means of 900 -m-deep wells. In the more densely populated southern part of Luxembourg, large areas are concerned with the conflicting uses of groundwater for drinking purposes and geothermal exploitation. This particularly hinders the areal development of heat pump systems in the shallow subsurface. Protected areas are shown in the national geoportal (ACT 2014). Two major aquifers, i.e., the sandstone-dominated Upper Buntsandstein and the Luxembourg Sandstone Formation, are used for provision of drinking water (Bintz 2003; Bintz et al. 1982, Lucius 1953). However, the exploited shallow groundwater resources ( $<200 \mathrm{~m}$ depth) are vulnerable for contamination.

Regarding the surrounding countries, the potential of geothermal energy in Belgium was assessed by Berckmans and Vandenberghe (1998), while the geothermal conditions of the Rhineland-Palatinate in Germany were presented by Storz (2007). Häfner et al.

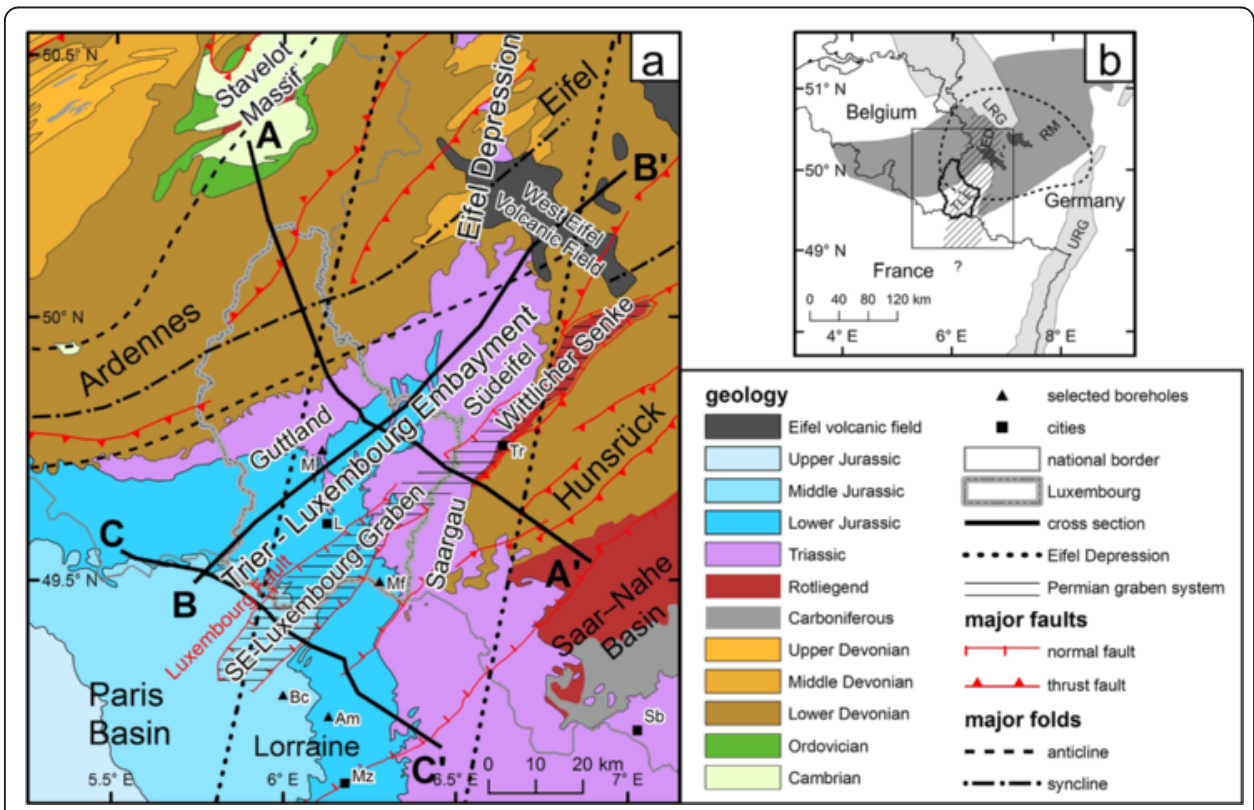

Figure 1 Geological map and simplified basement tectonic map. (a) Regional geological map of the study area. Geographical units are indicated. The location of the map within Western Europe is shown in (b). Main cities and boreholes are mentioned in the text. Black bold lines and letters indicate the cross sections $A$ to $A^{\prime}, B$ to $B^{\prime}$, and $C$ to $C^{\prime}$. (b) Simplified basement tectonic map of Luxembourg and the surroundings. Rectangle indicates location of geological map shown in (a) with indication of the Rhenish Massif (RM), the Lower and Upper Rhine Grabens (LRG and URG, respectively), the Eifel Depression (ED; hatched zone), and the Trier-Luxembourg Embayment (TLE). Dashed contour indicates the location of the Eifel plume according to Keyser et al. (2002). 
(2007) evaluated the possibility of using geothermal energy for space heating in the adjoining Trier-Bitburg region. A comprehensive study of mineral and thermal springs in the Eifel and Ardennes regions for geothermal anomalies was performed by Langguth and Plum (1984). In a recent and comprehensive study of the deep subsurface of Hesse (Germany) by means of 3-D modelling (Bär et al. 2011; and references therein), all types of deep geothermal applications, including hydrothermal and petrothermal systems as well as fault zones and deep borehole heat exchangers, were considered. At present, the adjoining areas of the Südeifel region in Germany (Figure 1) are not considered as targets for exploitation of hydrothermal reservoirs (Kaltschmitt et al. 1999; Stober et al. 2009). By contrast, the Paris Basin and the underlying Variscan basement in France are considered as potential areas for the development of geothermal resources (Bonté et al. 2010). For the Lorraine region in particular, the geothermal potential of shallow aquifers using heat pumps is presented by Bourgine et al. (2007). In Belgium (Berckmans and Vandenberghe 1998) and the German Rhineland-Palatinate (Storz 2007), the development of petrothermal systems using Enhanced/Engineered Geothermal Systems (EGS) are also not yet effective.

Until recently, the assessment of geothermal resources and their evaluation for different geothermal applications in Luxembourg and the adjoining areas was hampered by the absence of deep boreholes (Schintgen and Förster 2013) and lack of temperature prognosis at depth. Conceptual geological models incorporated into thermal models allow evaluating the possibilities for different types of geothermal uses and to pinpoint the most promising areas for geothermal exploration. The regional and local surface geology and conceptual subsurface models presented by Schintgen and Förster (2013) and Schintgen et al. (2015) form the basis for geothermal exploration presented in this paper. Two main types of geothermal reservoirs are considered: (1) the low-enthalpy hydrothermal reservoirs and (2) the petrothermal reservoirs for exploitation by EGS.

\section{Background on different types of geothermal utilizations}

Geothermal energy is stored as heat in rocks and trapped vapour or liquid such as water or brines (Muffler and Cataldi 1978; International Energy Agency 2011). The different possibilities for its utilization are also related to depth and subsurface temperatures and lead to the distinction of shallow and deep geothermal resources. Shallow geothermal energy refers to systems frequently using heat pumps for exploitation of near-surface environments characterized by temperatures $<20^{\circ} \mathrm{C}$ and depths $<400 \mathrm{~m}$ (Stober et al. 2009). Deep geothermal energy refers to direct use of geothermal heat at temperatures $>20^{\circ} \mathrm{C}$ (Líndal 1973; Saadat et al. 2010). Major applications are in spas and swimming pools for balneological purposes; in industry, for process heating, in agriculture for greenhouse or soil heating or in aquaculture for pond heating. For example, for greenhouse heating temperatures $>40^{\circ} \mathrm{C}$ are required, and for district and space heating, temperatures $>60^{\circ} \mathrm{C}$ (Pluymaekers et al. 2012). In order to efficiently use a wider temperature domain, different applications demanding successively lower temperatures are ideally implemented in a cascade (International Energy Agency 2011; Líndal 1973). Space cooling is also possible using geothermal heat with a minimum temperature of $60^{\circ} \mathrm{C}$ to $70^{\circ} \mathrm{C}$ as an energy source for heat-driven sorption chillers instead of electrically driven compression chillers (International Energy Agency 2011; Líndal 1973; Saadat et al. 2010). Another important field of application related to 
geothermal energy is the seasonal storage of solar energy or spare heat in deep aquifers (e.g., Stober and Bucher 2012).

In contrast to volcanologically active regions, low- and medium-enthalpy reservoirs, characterized by temperatures $<200^{\circ} \mathrm{C}$, are widespread in Europe and gain increasing attention because their potential is large and expandable (Kramers et al. 2012; Tester et al. 2006). Hydrothermal and petrothermal systems are distinguished. Hydrothermal systems are systems of warm or hot water present in deep aquifers or hydraulically conductive fault zones (Muffler and Cataldi 1978). Where natural permeability is too low for economic-technical use of geothermal energy, natural joints can be hydraulically stimulated or new fractures formed by injecting pressurized water to enhance permeability and create a heat exchanger, a procedure designated by EGS (Breede et al. 2013; Held et al. 2014; Huenges 2010). These are called petrothermal systems, unconventional geothermal resources or hot-dry rock (HDR) systems (Breede et al. 2013; ENGINE Coordination Action 2008). In contrast to hydrothermal systems, EGS predominantly makes accessible heat stored in rocks (Muffler and Cataldi 1978; Tester et al. 2006). Numerous existing EGS projects are still at pilot/demonstration scale (Breede et al. 2013) with a high proportion of R\&D funding, especially during the cost-intensive drilling and stimulation phases associated with exploration and geological-technical risks (Rybach 2010; Sperber et al. 2010; International Energy Agency 2011). The most common and simple type of a hydrothermal system is a hydrothermal doublet (two-well system), consisting of a reservoir heat exchanger commonly at a depth of several kilometers ( $<5$ to $6 \mathrm{~km}$ depth) exploited by a warm/ hot production well, a heat exchanger at the surface for transferring the heat to a secondary circuit and a cold injection well. For heat production only, it is possible to install deep coaxial pipes in a single borehole operating as closed systems independent from local geology.

The production of electricity in low- and medium-enthalpy systems is only possible in binary systems using working fluids with low boiling point, notably organic rankine cycle (ORC) power plants or Kalina systems based on an ammonia-water mixture, reaching an efficiency of $10 \%$ to $15 \%$ with minimum temperatures of about $120^{\circ} \mathrm{C}$ (ENGINE Coordination Action 2008). According to Garnish (2002) and Rybach (2010), for the deployment of EGS technology in petrothermal reservoirs, production rates of 50 to $100 \mathrm{l} \mathrm{s}^{-1}$ and fluid temperatures at wellhead of $150^{\circ} \mathrm{C}$ to $200^{\circ} \mathrm{C}$ are preferable. Most of the current European EGS projects are characterized by reservoir/bottomhole temperatures $<165^{\circ} \mathrm{C}$ (e.g., Bruchsal, Landau, Unterhaching, Insheim, Mauerstetten, Groß Schönebeck, Soultz; Breede et al. 2013) and worldwide operating flow rates frequently are $<40 \mathrm{l} \mathrm{s}^{-1}$ (Breede et al. 2013). From an economic and ecological point of view, the heat remaining after power production should be used according to the principle of cogeneration or combined heat and power generation (International Energy Agency 2011; Paschen et al. 2003). The technical lifetime of a doublet system usually is 30 years (e.g., Kramers et al. 2012), which is due to the fact that conductive heat flow within rock is too small to compensate heat extraction (Muffler and Cataldi 1978).

\section{Regional geology}

An adequate understanding of the geology and its structural/tectonic framework is of paramount importance for the evaluation of subsurface conditions, notably temperature 
and permeability, relevant for the identification and exploitation of geothermal reservoirs. Despite the limited size of the study area, regional geology is multifaceted. It is characterized by various sedimentary rocks ranging mainly from Cambrian through Mesozoic to Quaternary volcanics. Lithotypes range from metasediments such as Lower Paleozoic quartzite and slate, Lower Devonian shale, sandstone, quartzitic sandstone, and carbonates to Permian and Mesozoic claystone, siltstone, sandstone, conglomerate, marlstone, and carbonates (Schintgen et al. 2015). Figure 1 shows the major geological subunits of the study area and its location with respect to the Rhenish Massif (RM) and the European Cenozoic Rift System (ECRIS). As a geographical orientation, the major cities of Luxembourg (L), Trier (Tr), Metz (Mz), and Saarbrücken (Sb) are indicated in Figure 1. The Eifel Depression (Eifeler-Nord-Süd Zone) is interpreted as an important cross fold within the RM, separating the Ardennes (to the west side) from the Eifel region (to the east side) (Murawski et al. 1983). The study area is characterized by two contrasting geological environments, the Mesozoic rock of the Trier-Luxembourg Embayment (TLE) and the mostly Lower Devonian rock of the RM. The Wittlicher (Rotliegend) Senke (WS) represents a relatively narrow Permian Graben within the southwestern part of the RM (Stets 2004).

\section{Mesozoic and Rotliegend}

The TLE (Figure 1; in German: Trier-Luxemburger Bucht) refers to the present-day structure and appearance of the Mesozoic sedimentary record, which constitutes a tectonically enhanced and partially eroded counterpart of the former Trier-Luxembourg Basin (TLB; Dittrich et al. 2011, Dittrich 2014; Schintgen and Förster 2013). As shown in Figure 2, it is composed of subhorizontal layers of alternating hard and soft lithotypes of Triassic and Jurassic age. The TLE forms a northeastern extension of the Paris Basin

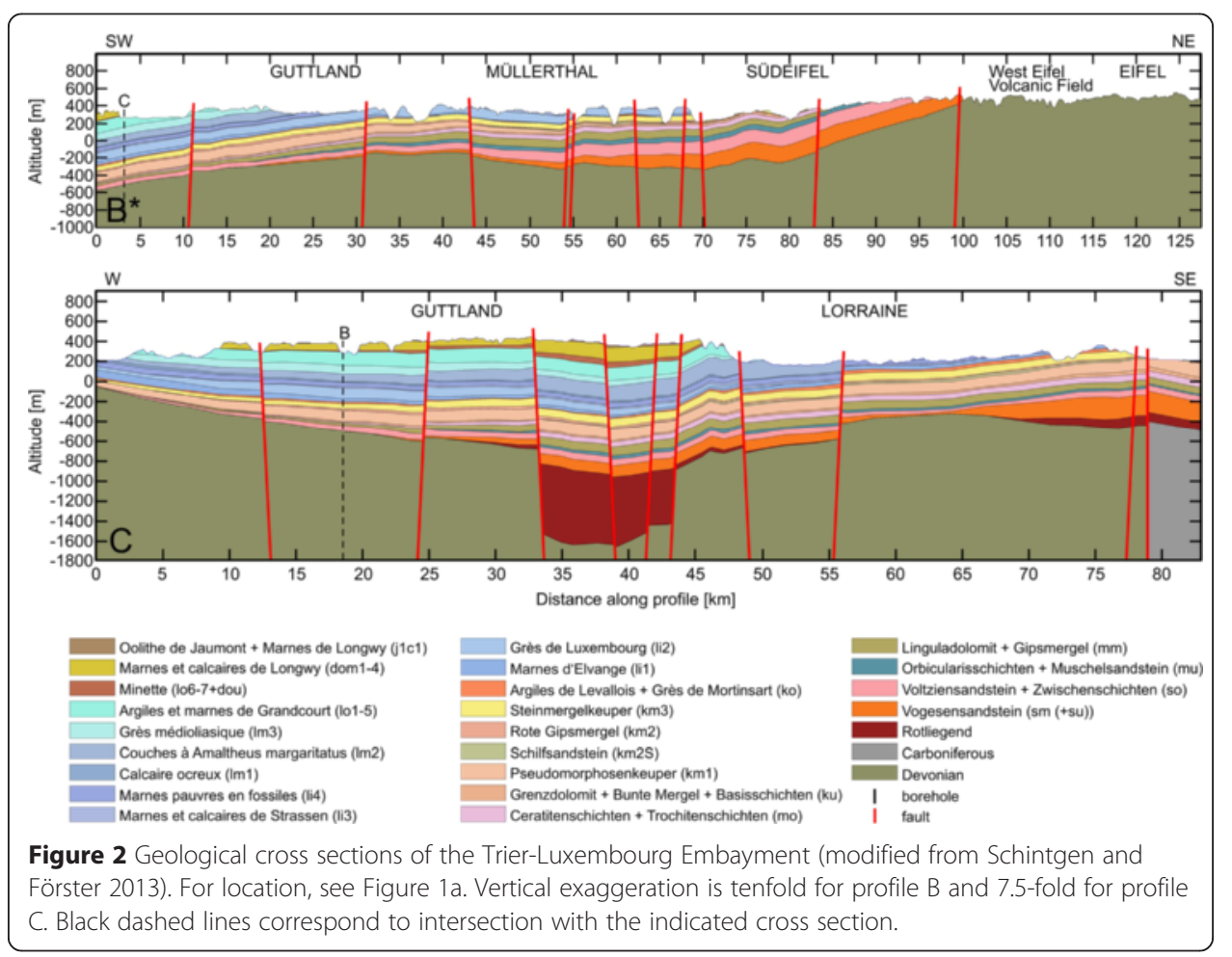


reaching about $80 \mathrm{~km}$ into the RM. Sub-regions of the TLE are the Guttland in Luxembourg and the Südeifel (South Eifel) and Saargau in Germany. The South Eifel region, encompassing the Bitburg and Trier sub-basins (Dittrich et al. 2011), is a geologically and structurally integral part of the TLE though the sub-regions are frequently handled separately on either side of the German-Luxembourgish border. According to Schintgen and Förster (2013), the development of the Mesozoic TLB is attributed to a synsedimentary zone of weakness of SW-NE orientation along a Permian graben system. It consists of a buried part, the SE-Luxembourg Graben (SELG), and a relatively wellknown exposed part, the Wittlicher Senke. In the Trier-Wittlich area, the infill of the 5to $10-\mathrm{km}$-wide graben is an about 1,000-m-thick succession of Rotliegend sediments. The dominantly siliciclastic lithotypes are breccia/conglomerates, sandstones, siltstone, and claystone of fluvial origin as well as an ignimbrite layer at its base (Stets 2004).

\section{Lower Devonian}

The Variscan basement of the RM is exposed in the Ardennes in Belgium and Luxembourg, as well as in the adjoining Eifel and Hunsrück regions in Germany, and is buried below the TLE (Figure 1a). The geology and structure of the study area are illustrated by cross sections in Figure 3. It is predominantly composed of thick Lower Devonian sediments characterized by a relatively homogeneous, shale-rich clastic-rock assemblage. Numerous thrust faults characterize the Hunsrück, whereas persistent fold structures are typical for the Ardennes and Eifel regions. Besides shale, all Lower Devonian formations contain a certain proportion of sandstone or quartzitic sandstone, but significant amounts are represented by the Taunusquarzit in the Hunsrück (e.g., Wildberger 1992; Stets and Schäfer 2011) and are known towards the base of the Devonian in the Ardennes (Bultynck and Dejonghe 2001; Dejonghe 2008). The underlying Caledonian basement (Ordovician and Cambrian), which is well exposed in the Stavelot-Venn Massif to the north of Luxembourg (Figure 1a), is not considered because its specific local geology is uncertain and it is mostly located too deep to be of interest for geothermal energy use (Figure 3). So far, the lack of deep boreholes

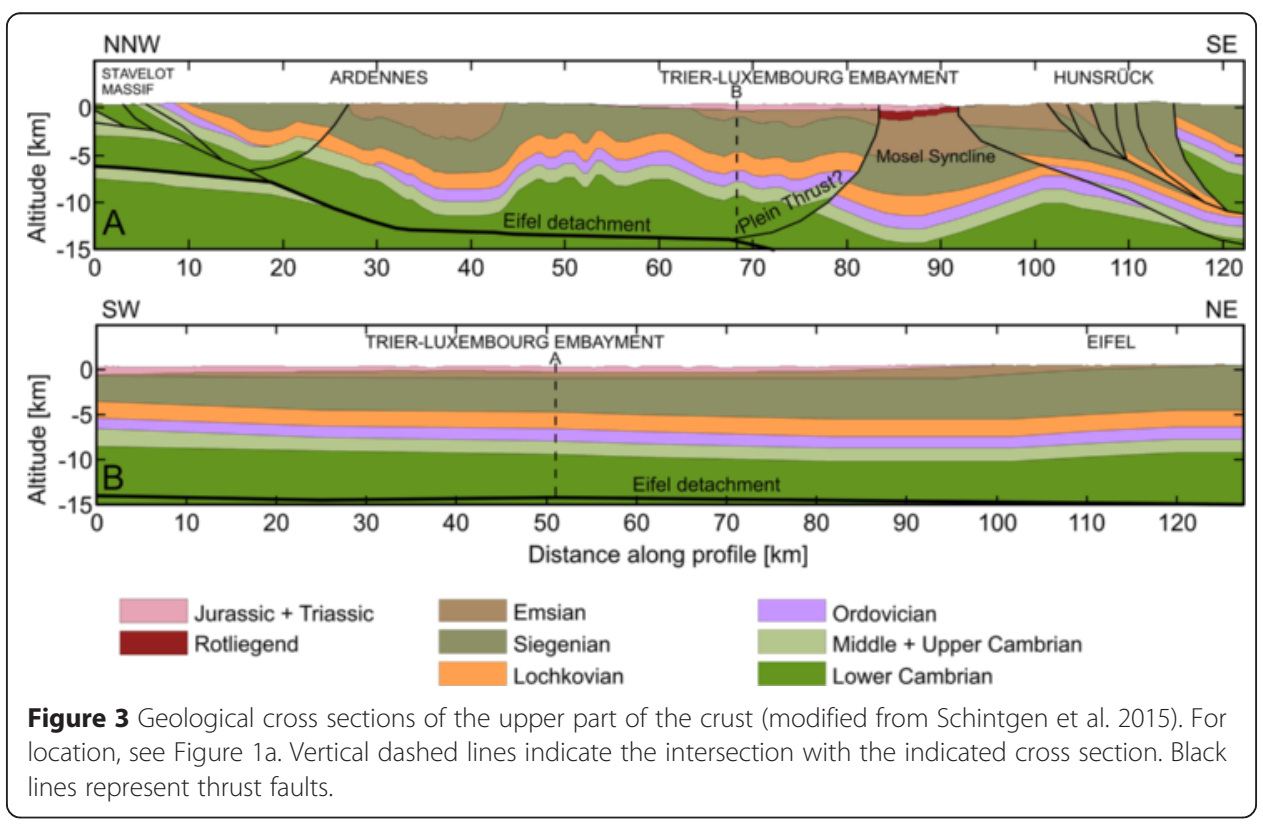


precludes knowledge about the distribution of lithologies and the stratigraphical position of known formations buried in the Lower Devonian basement.

\section{Cenozoic evolution}

From the Cenozoic to the present day, the TLE is undergoing active deformation (Dittrich 2014; and references therein). On a larger scale, the RM and adjoining areas are deformed and uplifted due to the development and evolution of the ECRIS (represented by the Lower Rhine Graben (LRG) and the Upper Rhine Graben (URG) in Figure 1b) since the Eocene about $40 \mathrm{Ma}$ ago (Bourgeois et al. 2007; Demoulin and Hallot 2009; Fuchs et al. 1983; Schmincke 2007; Dèzes et al. 2004; Ziegler and Dèzes 2007; and references therein). Intensified tectonic activity in the last $700 \mathrm{ka}$ is expressed by the accelerated uplift of the RM and young volcanism in the Eifel region (Demoulin and Hallot 2009; Fuchs et al. 1983; Meyer and Stets 2002; Schmincke 2007).

\section{Methods}

\section{Geothermal exploration}

For geothermal exploration and exploitation purposes, geological, thermal, hydrogeological, and structural data are necessary. In fact, especially in hydrothermal reservoirs, various lithologies, and facies changes are responsible for a large range of porosities and permeabilities. Subsurface temperatures represent important information for the identification of geothermal reservoirs because the temperature domain determines the types of geothermal energy use and applications that can be implemented. Hydraulic properties, notably permeability and the associated transmissibility, are crucial parameters because they dictate the technical feasibility of specific applications by directly influencing achievable flow rates and thus power output of a geothermal plant (e.g., Schulte et al. 2010). In hydrothermal as well as petrothermal reservoirs, the crustal stress field influences or controls the creation and evolution of faults, fractures, and joints, thus permeability, and therefore is particularly important for site selection for geothermal exploration and development of Enhanced Geothermal Systems (Cloetingh et al. 2010).

\section{Results and discussion}

\section{New temperature data}

As deep boreholes are scarce and temperature data are unavailable, the thermal regime was obtained by lithosphere-scale 2D steady-state thermal modelling based on surface heat flow and a vast database of measured thermal rock properties, in particular thermal conductivity (TC) (Schintgen et al. 2015). It is assumed that heat conduction is the main heat transfer mechanism in the lithosphere, which encompasses the crust and the lithospheric mantle. Possible convective as well as transient processes are so far unknown and were not quantified due to the lack of pertinent data. The thermal model by Schintgen et al. (2015) provides data for temperature maps (Figure 4) generated for 1-km-depth steps between 1,000 and 6,000 $\mathrm{m}$ (below mean sea level). Of particular interest are the temperatures encountered at a depth of 5 to $6 \mathrm{~km}$ to which geothermal boreholes can be drilled at costs that allow an economic use of the Earth's heat by combining heat production and power generation.

In contrast to an evaluation by Biermayr et al. (2007), the geothermal potential in Luxembourg cannot be negated a priori. In the following, it is shown that temperature 





gradients for the Mesozoic are higher than about $18^{\circ} \mathrm{C} \mathrm{km}^{-1}$ specified by Biermayr et al. (2007). According to recent TC data for lithotypes and entire formations and a surface heat flow value of $75 \mathrm{~mW} \mathrm{~m}$-2 $^{-2}$ evaluated by Schintgen et al. (2015), average thermal gradients amount to $27.8^{\circ} \mathrm{C} \mathrm{km}^{-1}$ in the Triassic and $32.6^{\circ} \mathrm{C} \mathrm{km}^{-1}$ in the Liassic and Dogger (or Lower and Middle Jurassic). The lower thermal gradient in the Triassic is related to a higher proportion of sandstone and evaporites such as dolomite presenting a high TC (median 3.2 and $3.8 \mathrm{~W} \mathrm{~m}^{-1} \mathrm{~K}^{-1}$, respectively). Except for the Luxembourg Sandstone Formation (median TC $3.6 \mathrm{~W} \mathrm{~m}^{-1} \mathrm{~K}^{-1}$ ), the Liassic marine sediments are generally more fine-grained and characterized by claystone, marlstone, and limestone of relatively low TC (median 2.1, 2.5, and $2.3 \mathrm{~W} \mathrm{~m}^{-1} \mathrm{~K}^{-1}$, respectively; Schintgen et al. 2015). The thermal gradient amounts to $30^{\circ} \mathrm{C} \mathrm{km}^{-1}$ for the entire Mesozoic represented in Luxembourg, which constitutes a value characteristic for similar geological environments, e.g., in France and in the Netherlands (Bonté et al. 2010, 2012). In the Paleozoic basement, temperature maps show at each depth a SW-NE-oriented plateau of maximum temperature (Figure 4a,b,c,d,e,f). For example, maximum temperatures at $5 \mathrm{~km}$ depth are in the range of $120^{\circ} \mathrm{C}$ to $125^{\circ} \mathrm{C}$ according to the thermal model by Schintgen et al. (2015). Temperature in the plateau region exhibits a thermal gradient of about $20^{\circ} \mathrm{C} \mathrm{km}^{-1}$ due to a higher TC of the compact rock in the basement in comparison to the Mesozoic sediments. In the northwest, in the Belgian Ardennes, temperatures are reduced by $5^{\circ} \mathrm{C}$ at $1,000 \mathrm{~m}$ depth increasing to $20^{\circ} \mathrm{C}$ at 5,000 and $6,000 \mathrm{~m}$ depth. The reduced temperature is associated with the thinning of the Emsian and Siegenian cover of relatively low TC $\left(3.2 \mathrm{~W} \mathrm{~m}^{-1} \mathrm{~K}^{-1}\right)$ and a shallow depth of the CambrianOrdovician basement of overall high TC (3.1 to $4.3 \mathrm{~W} \mathrm{~m}^{-1} \mathrm{~K}^{-1}$; Schintgen et al. 2015). In the southeast, in the Hunsrück region, temperatures are lower by $10^{\circ} \mathrm{C}$ at $1,000 \mathrm{~m}$ depth increasing to $30^{\circ} \mathrm{C}$ at $6,000 \mathrm{~m}$ depth. The reduced temperature is related to the high TC of the Taunusquarzit (approximately $5 \mathrm{~W} \mathrm{~m}^{-1} \mathrm{~K}^{-1}$ ).

\section{Implications from tectonics and stress field}

Besides the deep geological conditions and knowledge of the subsurface temperature distribution, the crustal stress field is particularly important in site selection for geothermal exploration and development of Enhanced Geothermal Systems. Inherited structures such as lithosphere-scale weakness zones formed under paleo-stress fields play a significant role in basin and lithosphere dynamics under present-day stress fields (Cloetingh et al. 2010). The previous tectonics and current activity affecting the eastern part/margin of the TLE have recently been studied in detail and reveal a complex network of polygenetic faults (Dittrich 2014; and references therein). The result is a subsided bloc mosaic where all types of faults, i.e., normal, reverse and strike-slip faults, and various combinations and reactivations, are observed (Dittrich 2008, 2009, 2011, 2012, 2013, 2014; Dittrich et al. 2011; Wagner 1996; Wagner et al. 2012; and references therein). The present-day NWSE-oriented principal stress direction, which has remained practically unchanged since the early Miocene (Dèzes et al. 2004; Ziegler and Dèzes 2007), is well expressed in the NW-SE orientation of the West Eifel volcanic field (WEVF) (Figure 1; Schmincke 2007). The TLE is currently characterized by a compressional tectonic regime (Dittrich 2014).

New interpretation of the Müllerthal-Südeifel region The Müllerthal region in Luxembourg and the adjoining Südeifel region in Germany correspond to the 
northeastern part of the TLE (Figure 1). Both the present-day appearance of the TLE, in particular of the South Eifel region, as well as the development of the TLB were classically interpreted to be of practically identical origin and linked to the Eifel Depression (e.g., Lucius 1948; Murawski et al. 1983; Wagner et al. 2012). Already challenged by Weiler (1972), this interpretation has been questioned (Dittrich 1989; Schintgen and Förster 2013). Detailed studies by Dittrich (2014; and references therein) show that the eastern part/margin of the TLE has been intensively deformed and subsided during the Cenozoic. In the following, the Cenozoic structural evolution of the Müllerthal-Südeifel region is reinterpreted for geothermal exploration using new data by Schintgen and Förster (2013). The present-day appearance of the TLE is likely the result of consecutive and superimposed large-scale structures formed in different geodynamic contexts. First, the Mesozoic TLB is suggested to have formed along the weakness zone of a Permian graben system (Schintgen and Förster 2013). Second, the South Eifel region was intensively mobile during the Cenozoic (Dittrich 2014; and references therein).

Cenozoic structural evolution of the Müllerthal-Südeifel Depression In order to underpin the aforegoing reasoning about the young development of the Müllerthal-Südeifel Depression (MSD), Figure 5a,b,c shows the palinspastic restoration of the South Eifel region to its probable Mesozoic synsedimentary structure by means of cross section B* (B to B'; Figure 1) showing the current bedding in the Trier-Luxembourg Embayment. For a clear visualization, the successive steps are shown with a tenfold vertical exaggeration. Cross section $\mathrm{B}^{* *}$ shows the pre-Tertiary, relatively undisturbed stratigraphic layering

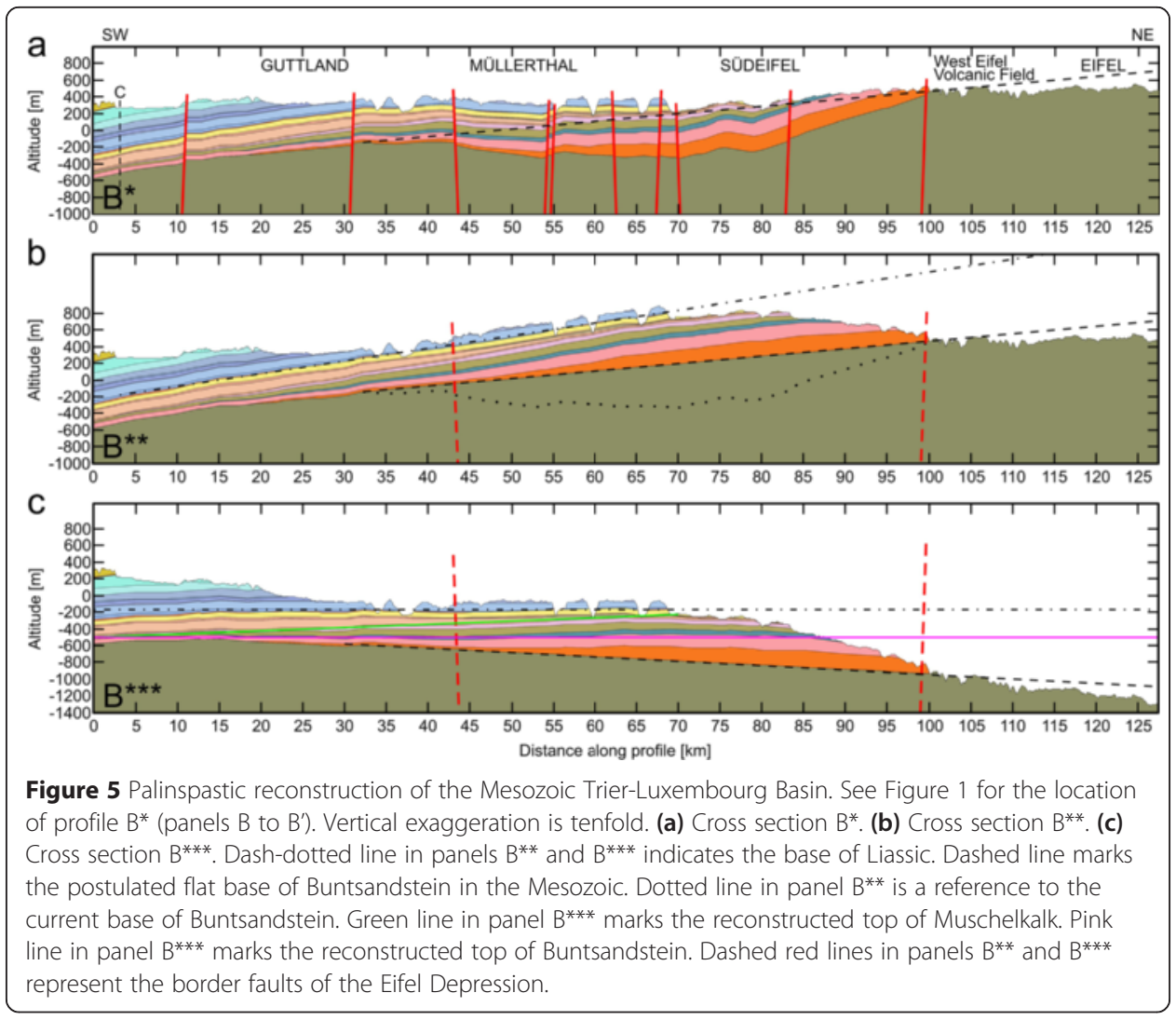


(bedding) of the TLB as it likely was before the development of the Eifel Depression, more specifically, as it probably was prior to the inferred Cenozoic subsidence of the Müllerthal and South Eifel regions. The reconstruction of the TLB is now possible because the conceptual model of Schintgen and Förster (2013) infers a culmination of the base of the Mesozoic underneath the Alzette River valley (Figure 5a; 30 to $45 \mathrm{~km}$ ) instead of the old concept of a subsided area underneath the central part of the Guttland. This new vision leads to a different understanding of the regional geological evolution. Cross section $\mathrm{B}^{*}$ is based on cross section G presented by Schintgen and Förster (2013). The latter is extended into the Eifel region using the cross section data by Wagner and Dittrich (2010). However, in large parts of the TLB the thickness of the Buntsandstein as the basal geological unit remains speculative (Dittrich et al. 2011; Wagner et al. 2012; and references therein). The reasons are the lack of appropriate boreholes in the deeper parts of the TLE and the locally complicated faulting, e.g., to the north of Trier. Kremb-Wagner et al. (2014), Wagner et al. (2012) and Weiler (1972) assume reduced Buntsandstein thicknesses along the eastern and southeastern margins of the TLE near Trier. By contrast, in this study, the adopted Buntsandstein thicknesses are more persistent and retrieved from recent studies by Dittrich et al. (2011), LGB and LUWG (2010), and Wagner and Dittrich (2010). An important assumption is that the subsidence of the Müllerthal-Südeifel area affects a zone of about 30 to $100 \mathrm{~km}$ in cross section B* (Figure 5a). According to the palinspastic reconstruction, it is postulated that the undisturbed top of the Devonian basement was flat prior to Buntsandstein deposition and thus in direct continuation of the undisturbed flat section in the southwestern part of Luxembourg ( 0 to $30 \mathrm{~km}$ in cross section $\mathrm{B}^{*}$ ). The absolute difference in height, i.e., the supposed amount of subsidence, between the constructed line and present-day top of basement is added to the stratigraphical data. Interestingly, as shown in Figure 5b, the reconstructed top of the Keuper succession is flat in the reconstructed basin geometry, which certainly was the case before marine transgression at the beginning of the Liassic. Cross section B*: in Figure $5 c$ shows the synsedimentary appearance of the Mesozoic Trier-Luxembourg Basin obtained after a northeastward rotation of $0.8^{\circ}$. The difference between Figure $5 \mathrm{~b}$ and Figure $5 \mathrm{c}$ illustrates a simple tilting from the former western margin of the German Triassic Basin to the present-day northeastern realm of the Paris Basin at the beginning of the Keuper as described by Schintgen and Förster (2013). Northeastward tilting during the Muschelkalk, then southwestward tilting of the basin towards the centre of the Paris Basin during the Keuper obviously compensated each other. If the preceeding assumptions are correct, the subsidence of the MSD and of the entire ED is entirely postLiassic, and probably largely Cenozoic, i.e., comparatively young, as are the structures studied by Dittrich (2014; and references therein). The current stratigraphical inclination of $0.8^{\circ}$ may be entirely attributed to the Cenozoic uplift of the RM in the northeastern realm of the study area, also represented as a rift signature by Bourgeois et al. (2007). Moreover, the inclination shown in Figure $5 \mathrm{~b}$ and the subsidence shown in Figure 5a probably are contemporaneous Cenozoic processes. Figure 5c clearly illustrates that the Triassic and Jurassic units covered large parts of the Eifel region prior to exhumation of the RM and consequent erosion. Conclusively, in case the sedimentary record of the TLE represents a simple western margin of the German Triassic Basin, the Buntsandstein thickness should more or less constantly decrease from the east to the west (Figure $5 \mathrm{c}$ ), which is basically not in contradiction with the newest thickness data reported by Dittrich et 
al. (2011). In the central part of the MSD, the average Cenozoic subsidence amounts to $470 \mathrm{~m}$ according to Figure $5 \mathrm{~b}$, which is comparatively more than the $350 \mathrm{~m}$ of Cenozoic subsidence in the Neuwied tectonic basin (Schmincke 2007). A clear evidence for the current relative subsidence of the MSD within the uplifting Rhenish Massif is presented by Mälzer et al. (1983). During the last $40 \mathrm{Ma}$ of evolution of the ECRIS, the average relative subsidence rate of the MSD amounts to $0.01 \mathrm{~mm} \mathrm{a}^{-1}$. If the relative subsidence is supposed to be $100 \mathrm{~m}$ (Meyer and Stets 2002, 2007) in the last $700 \mathrm{ka}$ (Schmincke 2007), the average relative subsidence rate amounts to $0.14 \mathrm{~mm} \mathrm{a}^{-1}$, i.e., a tenfold acceleration. The latter rate corresponds to the instantaneous, relative height changes between the Eifel and the South Eifel regions determined by Mälzer et al. (1983). To sum up, it is not the development of the Mesozoic TLB itself but the appearance of the present-day TLE, in particular, the structure of the MSD, that is linked to the formation of the Eifel Depression.

\section{Lithology and structure - implications on hydrogeology}

The study area is characterized by two geologically and hydrogeologically contrasting environments, the Mesozoic rock of the TLE and the predominantly Lower Devonian rock of the RM. According to Bintz et al. (1982), Lucius (1953) and LGB and LUWG (2010), the exposed compact, often shale-rich, and folded and thrust rocks of the Ardennes, Eifel, and Hunsrück are not capable of hosting large aquifers, whereas the subhorizontal and persistent layers of the TLE are composed of alternately permeable and impermeable lithologies suitable for the formation of significant aquifers.

Mesozoic of the Trier-Luxembourg Embayment From top to bottom, six major aquifers are known in the TLE (Lucius 1953; Bintz et al. 1982). Figure 6 shows SW-NEand W-SE-oriented hydrogeological cross sections across the TLE. Major aquifers are highlighted by their typical color codes and stratigraphical codes used in Luxembourg. Among those, the limestone and Minette complex (dom1-4 and lo6-7+dou) and the Middle Liassic Sandstone $(\operatorname{lm} 3)$ are the shallowest and only cover a small extent in the

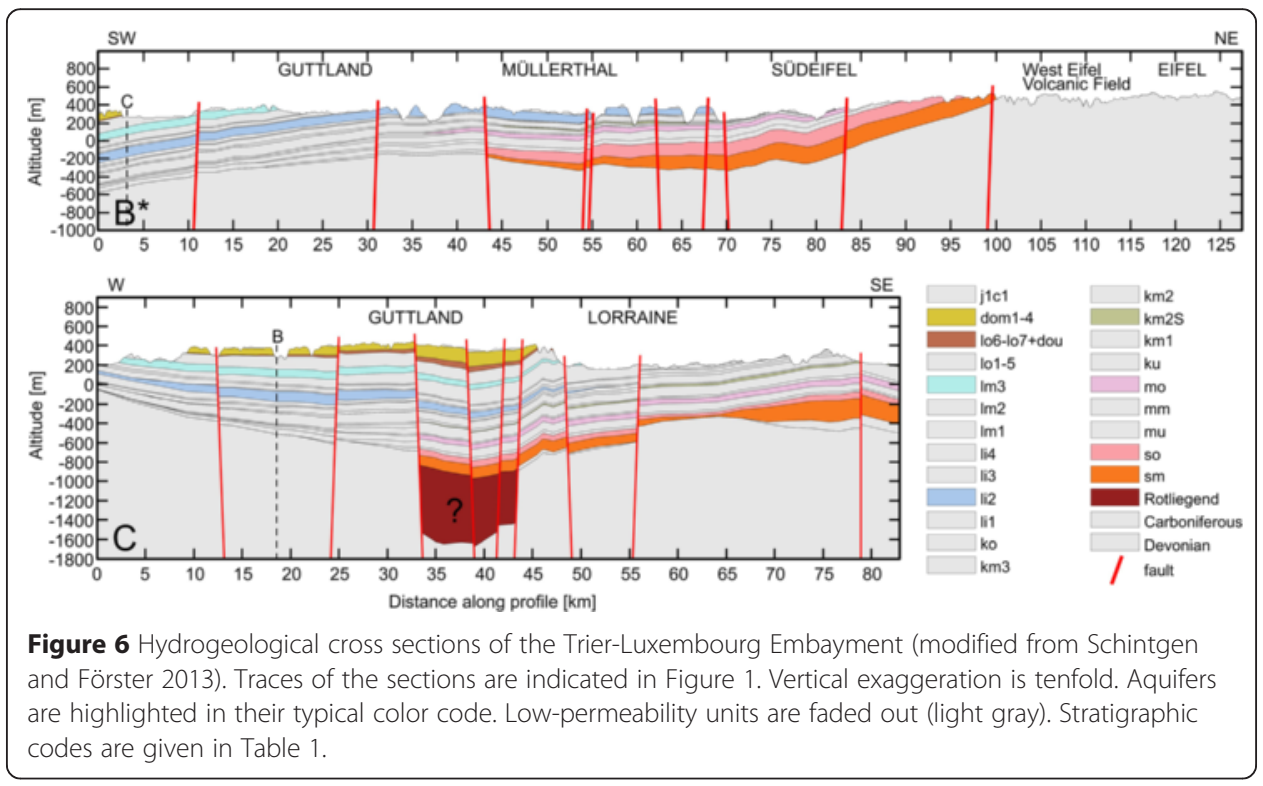


southwestern part of Luxembourg. The typical Schilfsandstein (km2S; Stuttgart Fm.) also has a limited extent in the eastern part of the TLE and is locally exposed. Three aquifers are more extensive in Luxembourg and adjoining areas: the Luxembourg Sandstone (li2), the Upper Muschelkalk dolomite (mo), and the Buntsandstein formations (so2+so1+sm). Table 1 summarizes the hydraulic properties of the Mesozoic formations including their degrees and values of hydraulic conductivity $\left(k_{f}\right)$ adopted by LGB and LUWG (2010) for equivalent formations of the South Eifel region. The Luxembourg Sandstone Formation is a shallow aquifer in the northeastern part of the TLE (Figure 6, cross section $B^{*}$ ) and is significantly used as a drinking water resource, which creates a conflicting use (ACT 2014). Therefore, the Luxembourg Sandstone may only be exploited in the southwestern part of Luxembourg where its thickness is in the range of 70 to $100 \mathrm{~m}$ and its top reaches a depth of 300 to $400 \mathrm{~m}$ (Figure 6). The Upper Muschelkalk aquifer has a regional occurrence but presents both a relatively impermeable margin facies and a reduced thickness in the western part of the TLE. The basin facies generally presents a thickness in the range of 40 to $60 \mathrm{~m}$ with an average value of about $55 \mathrm{~m}$ in the southeastern part of the TLE. The natural porosity is very low (2\%), except in the eastern part of the TLE where a dense fault network and shallow position lead to a locally very high permeability. The lowermost aquifer in the TLE is the Buntsandstein (Figure 6) encompassing mainly three (locally four if the Lower Muschelkalk aquifer is considered) stratigraphical units, namely the Voltziensandstein (so2), the Zwischenschichten (so1), and the Vogesensandstein (sm+su; Table 1). The generally least permeable basin facies in the northwestern part of the TLE is up to $150 \mathrm{~m}$ thick, whereas the most permeable basin facies of the Buntsandstein in the southeastern part of the TLE is mostly about 150 to $300 \mathrm{~m}$ thick (Schintgen and Förster 2013; Weiler 1991). Figure 7 presents the top and base, thus the geometry, of the Buntsandstein aquifer mapped using conceptual models in the form of cross sections for Luxembourg by Schintgen and Förster (2013) and LGB and LUWG (2010) and Wagner and Dittrich (2010) for Germany. Additional data is provided by boreholes in Luxembourg, France, and Germany as well as the most recent geological maps of Luxembourg, Rhineland-Palatinate, Saarland, and France. For the top of the Buntsandstein aquifer, additional depth maps by Coiffait and Ricour (1982) and Weiler (1972) were considered. Due to its appropriate depth and temperature and known excellent hydraulic properties (Agence de l'eau Rhin-Meuse 2002; Weiler 1972, 1991; Weidenfeller et al. 2004), the Buntsandstein aquifer is important for geothermal use and considered in more detail. The amount of geothermal energy extractable from a hydrothermal reservoir is a function of fluid properties such as temperature and mineralization, but achievable flow rates are crucial.

Hydrogeology of the Buntsandstein aquifer Among the aquifers of the TLB, the Buntsandstein aquifer is the deepest, thickest, and has the largest extent. The sandstone-dominated Buntsandstein is a heterogeneous, mixed fracture/pore aquifer (Celle-Jeanton et al. 2009; LGB and LUWG 2010; Weiler 1991). Figure 8 gives an overview of the hydrogeology of the Buntsandstein aquifer, including the water table as well as known permeable and impermeable zones. Data on the level of the water table in boreholes being scarce, equipotential lines in Luxembourg are completed using river levels in outcrop areas and available maps of the adjoining areas (Agence de l'eau 
Table 1 Hydraulic and thermal properties of the Mesozoic units

\begin{tabular}{|c|c|c|c|c|c|c|c|c|c|c|c|c|c|c|}
\hline \multirow{2}{*}{\multicolumn{3}{|c|}{ Stratigraphy }} & \multirow{2}{*}{\multicolumn{2}{|c|}{ Geological unit/formation }} & \multirow{3}{*}{$\begin{array}{l}\begin{array}{l}\text { Hydraulic } \\
\text { conductivity }\end{array} \\
\text { Average to moderate }^{\mathrm{a}}\end{array}$} & \multirow{3}{*}{$\begin{array}{l}\boldsymbol{k}_{\boldsymbol{f}} \\
{\left[\mathrm{m} \mathrm{s}^{-1}\right]} \\
10^{-3} \text { to } 10^{-5 a}\end{array}$} & \multirow{3}{*}{$\begin{array}{l}K \\
{\left[\mathrm{~m}^{2}\right]} \\
10^{-10} \text { to } 10^{-12}\end{array}$} & \multirow{3}{*}{$\begin{array}{l}\text { [mD] } \\
10^{5} \text { to } 10^{3}\end{array}$} & \multirow{4}{*}{$\begin{array}{l}\text { Aquifer } \\
+\end{array}$} & \multirow{4}{*}{$\begin{array}{l}\frac{H}{\text { Min. }} \\
{[\mathrm{m}]} \\
70\end{array}$} & \multirow{4}{*}{$\begin{array}{l}\begin{array}{l}\text { Max. } \\
{[\mathrm{m}]}\end{array} \\
130\end{array}$} & \multirow{4}{*}{$\begin{array}{l}\phi_{\text {tot }} \\
{[\%]} \\
14\end{array}$} & \multirow{3}{*}{\multicolumn{2}{|c|}{$\begin{array}{l}\lambda \\
\begin{array}{ll}\text { Dry Sat. } \\
{\left[\mathrm{W} \mathrm{m}^{-1} \mathrm{~K}^{-1}\right]}\end{array}\end{array}$}} \\
\hline & & & & & & & & & & & & & & \\
\hline & & & & & & & & & & & & & & \\
\hline \multirow[t]{15}{*}{ Jurassic } & Dogger & Middle & Marnes sableuses d'Audun-le-Tiche & dom4 & & & & & & & & & & \\
\hline & & & Calcaires d'Audun-le-Tiche & & & & & & & & & & & \\
\hline & & & Calcaire de Haut-Pont & dom3 & & & & & & & & & & \\
\hline & & & Calcaire d'Ottange & dom2 & & & & & & & & & & \\
\hline & & & Marnes micacées & dom1 & & & & & & & & & & \\
\hline & & Lower & Minette & dou & Average to moderate ${ }^{a}$ & $10^{-3}$ to $10^{-5 a}$ & $10^{-10}$ to $10^{-12}$ & $10^{5}$ to $10^{3}$ & + & 11 & 68 & 18 & 1.5 & 2.2 \\
\hline & Liassic & Upper & & $106-7$ & & & & & & & & & & \\
\hline & & & Argiles et marnes de Grandcourt & lo1-5 & Low $^{a}$ & $10^{-5}$ to $10^{-7 a}$ & $10^{-12}$ to $10^{-14}$ & $10^{3}$ to 10 & - & 100 & $140 ?$ & 20 & 1.1 & 2.0 \\
\hline & & Middle & Grès médioliasique & $\operatorname{lm} 3 a+b$ & Moderate to low ${ }^{\mathrm{a}}$ & $10^{-4}$ to $10^{-7 a}$ & $10^{-11}$ to $10^{-14}$ & $10^{4}$ to 10 & $+/-$ & 35 & 80 & 18 & 1.3 & 2.0 \\
\hline & & & Couches à Amaltheus margaritatus & $\operatorname{lm} 2$ & Low to very low ${ }^{a}$ & $10^{-5}$ to $10^{-9 a}$ & $10^{-12}$ to $10^{-16}$ & $10^{3}$ to $10^{-1}$ & - & 80 & $150 ?$ & 19 & 1.2 & 2.1 \\
\hline & & & Calcaire ocreux & $\operatorname{lm} 1$ & Low $^{a}$ & $10^{-5}$ to $10^{-7 a}$ & $10^{-12}$ to $10^{-14}$ & $10^{3}$ to 10 & - & 4 & 15 & 16 & 1.4 & 2.1 \\
\hline & & Lower & Marne pauvre en fossiles & li4 & Low $^{a}$ & $10^{-5}$ to $10^{-7 a}$ & $10^{-12}$ to $10^{-14}$ & $10^{3}$ to 10 & - & 30 & 45 & 9 & 1.7 & 2.3 \\
\hline & & & Marnes et calcaires de Strassen & li3 & Low to very low & $10^{-5}$ to $10^{-9}$ & $10^{-12}$ to $10^{-16}$ & $10^{3}$ to $10^{-1}$ & - & 8 & 40 & 6 & 1.6 & 1.8 \\
\hline & & & Grès de Luxembourg & li2 & Moderate to low & $10^{-4}$ to $10^{-7}$ & $10^{-11}$ to $10^{-14}$ & $10^{4}$ to 10 & + & 0 & 100 & 17 & 2.3 & 3.6 \\
\hline & & & Marnes d'Elvange & li1 & Low to very low & $10^{-5}$ to $10^{-9}$ & $10^{-12}$ to $10^{-16}$ & $10^{3}$ to $10^{-1}$ & - & 0 & 35 & 8 & 1.5 & 1.8 \\
\hline \multirow[t]{5}{*}{ Triassic } & Keuper & Upper & Argiles de Levallois & ko2 & Moderate to very low & $10^{-4}$ to $10^{-9}$ & $10^{-11}$ to $10^{-16}$ & $10^{4}$ to $10^{-1}$ & $+/-$ & 0 & 17 & 9 & 1.6 & 2.1 \\
\hline & & & Grès de Mortinsart & ko1 & & & & & & & & & & \\
\hline & & Middle & Steinmergelkeuper & km3 & Low to very low & $10^{-5}$ to $10^{-9}$ & $10^{-12}$ to $10^{-16}$ & $10^{3}$ to $10^{-1}$ & - & 20 & 75 & 8 & 2.0 & 2.4 \\
\hline & & & Rote Gipsmergel & $\mathrm{km} 2$ & Low to very low & $10^{-5}$ to $10^{-9}$ & $10^{-12}$ to $10^{-16}$ & $10^{3}$ to $10^{-1}$ & - & 15 & 30 & 9 & 1.8 & 2.3 \\
\hline & & & Schilfsandstein & $\mathrm{km} 2 \mathrm{~S}$ & Moderate to low & $10^{-4}$ to $10^{-7}$ & $10^{-11}$ to $10^{-14}$ & $10^{4}$ to 10 & $+/-$ & 0 & 50 & $28 ?$ & 1.0 & 1.9 \\
\hline
\end{tabular}


Table 1 Hydraulic and thermal properties of the Mesozoic units (Continued)

\begin{tabular}{|c|c|c|c|c|c|c|c|c|c|c|c|c|c|}
\hline & & Pseudomorphosenkeuper & $\mathrm{km} 1$ & Low to very low & $10^{-5}$ to $10^{-9}$ & $10^{-12}$ to $10^{-16}$ & $10^{3}$ to $10^{-1}$ & - & 20 & 100 & 11 & 1.6 & 2.2 \\
\hline & Lower & Grenzdolomit & ku & Low to very low & $10^{-5}$ to $10^{-9}$ & $10^{-12}$ to $10^{-16}$ & $10^{3}$ to $10^{-1}$ & - & 10 & 25 & 12 & 1.5 & 2.0 \\
\hline & & Bunte Mergel & & & & & & & & & & & \\
\hline & & Basisschichten & & & & & & & & & & & \\
\hline \multirow[t]{6}{*}{ Muschelkalk } & Upper & Ceratitenschichten & mo2 & Average to moderate & $10^{-3}$ to $10^{-5}$ & $10^{-10}$ to $10^{-12}$ & $10^{5}$ to $10^{3}$ & + & 10 & 55 & 2 & 3.8 & 3.8 \\
\hline & & Trochitenschichten & mo1 & & & & & & & & & & \\
\hline & Middle & Linguladolomit & $\mathrm{mm} 2$ & Average to moderate & $10^{-3}$ to $10^{-5}$ & $10^{-10}$ to $10^{-12}$ & $10^{5}$ to $10^{3}$ & + & 0 & 7 & 4 & 3.0 & 3.3 \\
\hline & & Gipsmergel & $\mathrm{mm} 1$ & Very low & $10^{-7}$ to $10^{-9}$ & $10^{-14}$ to $10^{-16}$ & 10 to $10^{-1}$ & - & 30 & 100 & 5 & 2.4 & 2.7 \\
\hline & Lower & Orbicularisschichten & mu2 & Moderate to low & $10^{-4}$ to $10^{-7}$ & $10^{-11}$ to $10^{-14}$ & $10^{4}$ to 10 & + & 10 & 50 & 10 & 1.8 & 2.4 \\
\hline & & Muschelsandstein & mu1 & & & & & & & & & & \\
\hline \multirow[t]{4}{*}{ Buntsandstein } & Upper & Voltziensandstein & $\mathrm{so} 2$ & Moderate to low & $10^{-4}$ to $10^{-7}$ & $10^{-11}$ to $10^{-14}$ & $10^{4}$ to 10 & + & 50 & 150 & 17 & 1.7 & 2.8 \\
\hline & & Zwischenschichten & sol & & & & & & & & & & \\
\hline & Middle & Vogesensandstein & sm & Moderate to low & $10^{-4}$ to $10^{-7}$ & $10^{-11}$ to $10^{-14}$ & $10^{4}$ to 10 & + & 0 & $>150$ & 21 & 1.9 & 3.0 \\
\hline & Lower & & su & Moderate to low & $10^{-4}$ to $10^{-7}$ & $10^{-11}$ to $10^{-14}$ & $10^{4}$ to 10 & + & & & & & \\
\hline
\end{tabular}

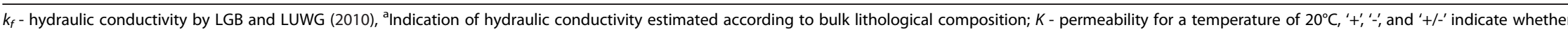
a unit is known, not known, or partly known to have aquifer quality, respectively; $H$ - common thickness range; $\phi_{\text {tot }}$ - total porosity; $\lambda$ - thermal conductivity in dry (Dry) and water-saturated (Sat.) conditions measured perpendicular to bedding. Thickness, porosity, and thermal conductivity values by Schintgen et al. (2015). 


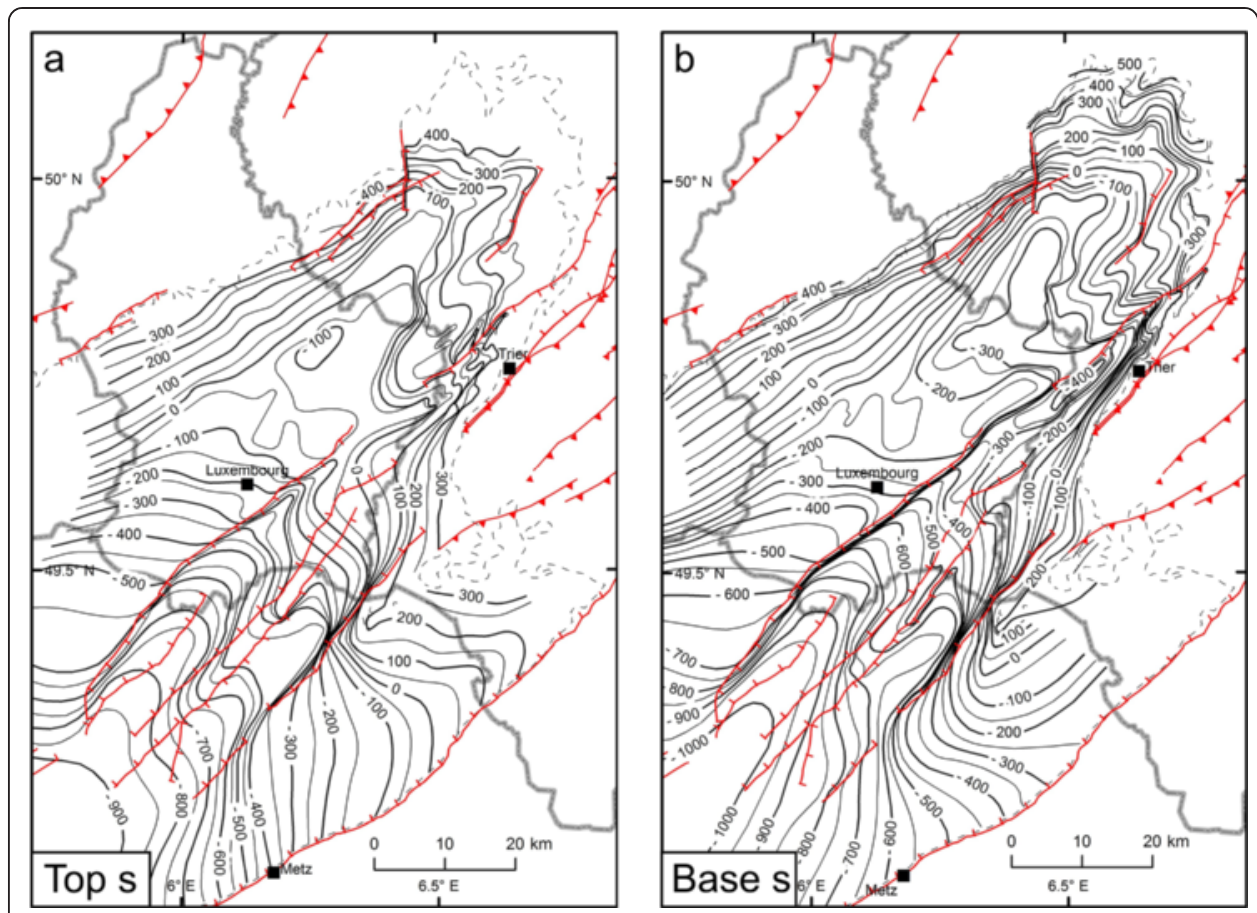

Figure 7 Simplified geometry of the Buntsandstein aquifer.(a) Top and (b) base. Depth (m) relative to mean sea level. Only major faults are shown.

Rhin-Meuse 2002; Celle-Jeanton et al. 2009; Weidenfeller et al. 2004; Weiler 1991). A narrow zone along the northern margin of the TLE is intensively used as a drinking water resource (Lucius 1953; Bintz 2003). Figure 8 shows a large zone of low permeability of the Buntsandstein aquifer related to a clay-rich and well-cemented margin facies in most of the northwestern part of the TLE. According to borehole reports available at the Geological Survey of Luxembourg, low permeabilities of the Buntsandstein (productivity $<10 \mathrm{~m}^{3} \mathrm{~h}^{-1}$ ) have been measured in the Rebierg (Rb), SES Koerich (Ko), Mersch (M), and Reisdorf (Rd) boreholes. Similarly, low permeabilities are known in France in the Longwy (Lw) and Audun-le-Roman (Ad) boreholes (BRGM 2015). The available data suggest that the Buntsandstein below the Müllerthal region in Luxembourg also has a low permeability. In the South Eifel region, low permeabilities are described by Kremb-Wagner (1996) and Weiler (1991). The W-E-oriented zone of low permeability forms a major barrier for groundwater flow (Weiler 1991). To the south, in the 460-m-deep Echternacherbrück (Eb) borehole located close to the German-Luxembourgish border (Figure 8), the Buntsandstein productivity is significantly higher $\left(40\right.$ to $50 \mathrm{~m}^{3} \mathrm{~h}^{-1}$ ). The Buntsandstein aquifer is drained beneath the southeastern part of the TLE towards the Moselle, Saar, and Sauer valleys (Figure 8). Evidence for drainage of the Buntsandstein is known in the Lower Sauer and Moselle valleys by ascending mineralized springs through faults even where the Buntsandstein is not directly exposed (Lucius 1953). A well productivity of 30 to $150 \mathrm{~m}^{3} \mathrm{~h}^{-1}$ is observed in Lorraine (Agence de l'eau Rhin-Meuse 2002) and in the Saargau (Weidenfeller et al. 2004). Average hydraulic conductivity in the South Eifel and Lorraine regions is practically the same and amounts to about $10^{-5}$ to $5 \times 10^{-5} \mathrm{~m} \mathrm{~s}^{-1}$ (permeability of 1 to $5 \mathrm{D}$ ) (Celle-Jeanton et al. 2009; LGB and LUWG 2010). High permeabilities and productivities 


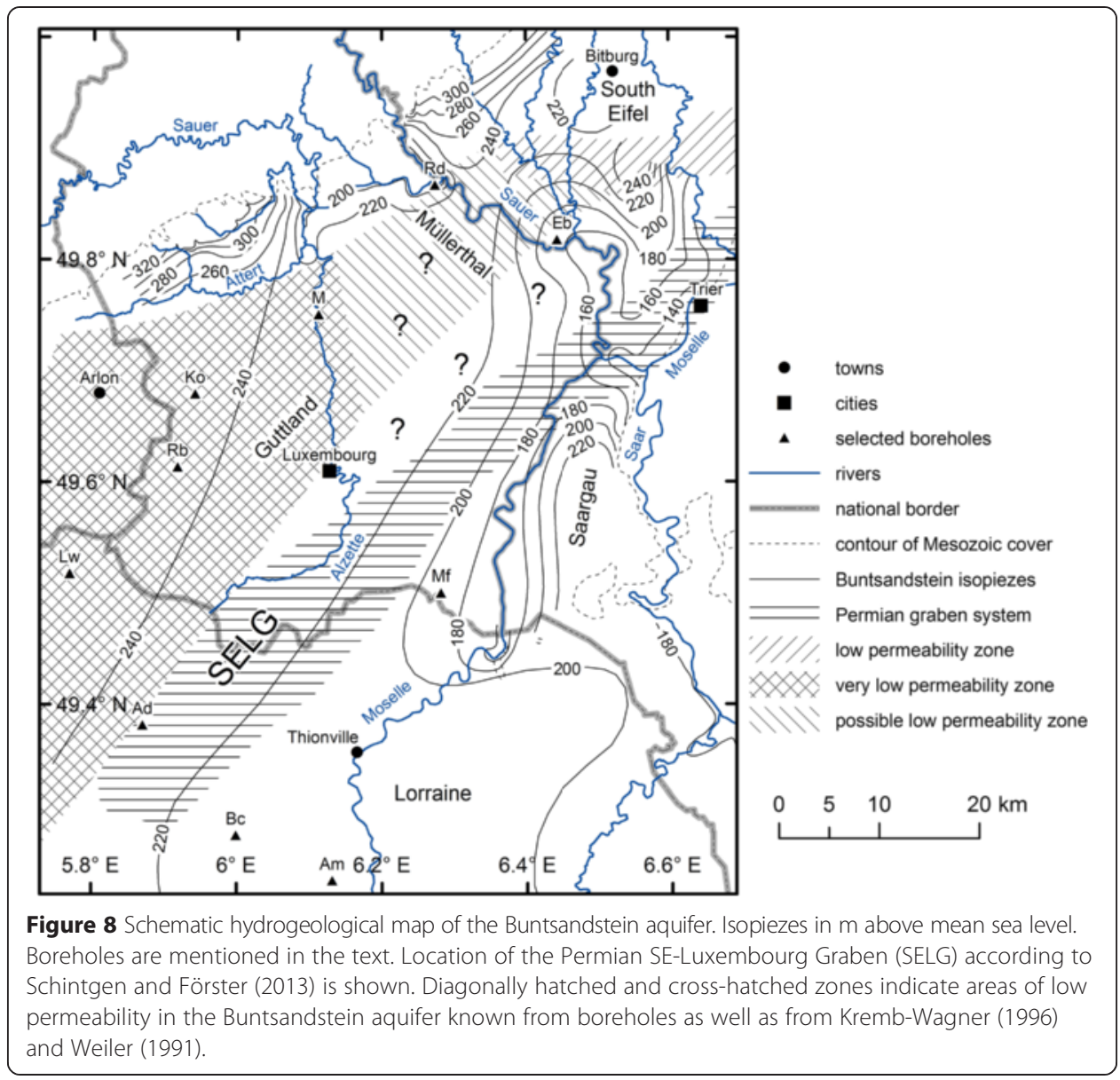

in those regions as well as in the southeastern part of the TLE are probably due to a high thickness of the Buntsandstein aquifer and a complex fault/fracture network (Dittrich 2014; and references therein) that is hydraulically conductive. Effective porosities in Luxembourg are unknown, but effective porosities of the basin facies in the northeastern part of Lorraine are 2\% to 5\% according to Agence de l'eau Rhin-Meuse (2002) and relatively high, in the range of $10 \%$ to $15 \%$ according to Celle-Jeanton et al. (2009). However, as porosity decreases due to compaction with depth, porosity is subordinate at greater depth and the presence of faults, fractures, and joints is crucial for permeability (Ledru and Guillou-Frottier 2010). The only location in Luxembourg where reliable hydraulic properties in the basin facies were determined using different techniques (Theis and Papadopoulos-Cooper) is the Mondorf Lucius borehole (Mf in Figure 8). According to Leichtle (1980), the average hydraulic conductivity $k_{f}$ is about $10^{-6} \mathrm{~m} \mathrm{~s}^{-1}$, i.e., 10 to 50 times lower than in areas where the Buntsandstein is exposed $\left(10^{-5}\right.$ to $\left.5 \times 10^{-5} \mathrm{~m} \mathrm{~s}^{-1}\right)$. This might be related to lower effective porosities due to a more fine-grained facies, a higher compaction, a lower fault density, as well as a higher mineralized fluid and higher rock cementation. The resulting average permeability $\left(\right.$ at $\left.20^{\circ} \mathrm{C}\right)$ amounts to $100 \mathrm{mD}$. The measured productivity varies from 6.3 to $14.2 \mathrm{l} \mathrm{s}^{-1}$ (Leichtle 1980). The productivity of the Lucius and Bois-châté boreholes (about $36 \mathrm{~m}^{3} \mathrm{~h}^{-1}$ ) thereby is in the lower zone of productivity of wells in the Buntsandstein $\left(30\right.$ to $150 \mathrm{~m}^{3} \mathrm{~h}^{-1}$ ). Mineralization in the central and deeper parts of the TLE known from boreholes and springs is in the range 12 to 
$16 \mathrm{~g} \mathrm{l}^{-1}$ (Lucius 1948) with a maximum of about $23 \mathrm{~g} \mathrm{l}^{-1}$ in the Bois-châté borehole (Nicklès 1914).

Hydrogeology of the Rotliegend Schintgen and Förster (2013) infer the existence of a 5- to 10-km-wide Rotliegend graben, designated by SELG. It is located in direct southwestern prolongation of the Wittlicher Senke and buried below the TLE. By parallelization with the about 1,000-m-thick succession of Rotliegend in the Trier area (Stets 2004), a set of yet unknown deep aquifers may exist in the southeastern part of Luxembourg. Hydraulic properties of the Rotliegend formations according to LGB and LUWG (2010) for the Wittlicher Senke are summarized in Table 2. The hydrogeological conditions in the Rotliegend are essentially known from the Wittlicher Senke. The small-scale lithological contrasts are responsible for a relatively heterogeneous fracture (joint, fissure) aquifer characterized by a moderate to very low permeability $\left(10^{-11}\right.$ to $10^{-16} \mathrm{~m}^{2}$; LGB and LUWG 2010). According to Stets (2004), the depositional environment in the Rotliegend consisted in a changeful fluviatile system and the siliciclastic infill of the graben structure is heterogeneous. It is therefore difficult to constrain permeable reservoirs. In contrast to the overlying Buntsandstein aquifer, the groundwater in the Rotliegend sediments is highly mineralized and the permeability is predominantly lower (LGB and LUWG 2010). Due to the lack of exploration boreholes in situ, porosity and permeability in these siliciclastic deposits of fluvial origin cannot be ascertained.

Lower Devonian of the Ardennes, Eifel, and Hunsrück Lower Devonian formations of the Eifel region including the South Eifel area were analyzed for their hydraulic properties by LGB and LUWG (2010). The resulting ranges of hydraulic conductivity (or conductivity classes) are summarized in Table 2. To the remaining Siegenian and Lochkovian formations for which hydraulic data is unavailable, estimates of hydraulic conductivity are assigned depending on their individual lithological composition. The shale-dominated Lower Devonian formations generally have permeabilities (or rather hydraulic conductivities) lower by several orders of magnitude with respect to those of the Buntsandstein in the TLE (Table 1). The Lower Devonian basement therefore forms the impermeable base of the Buntsandstein aquifer where the Rotliegend is absent (LGB and LUWG 2010; Lucius 1948). Compact sedimentary rock can be used to create artificial heat exchangers using EGS technology (Breede et al. 2013; Schulte et al. 2010; Tester et al. 2006; Zimmermann et al. 2011). Lower Devonian lithologies best suited for geothermal exploitation are deep-lying, thick, and laterally persistent layers with a high proportion of sandstone and/or quartzite with a possible fracture porosity/permeability. Most of the Lower Devonian formations contain a certain proportion of sandstone, frequently between $15 \%$ and $30 \%$. However, the Saint-Hubert and Fépin formations of Lochkovian age at the base of the Devonian in the Ardennes contain large and relatively thick packages of sandstone/quartzite (Dejonghe 2008) and therefore are described in more detail below. Figure 9 shows a schematic map of the top and base of the Lochkovian succession based on the conceptual geological cross sections presented by Schintgen et al. (2015). Major thrust faults shown are located at their inferred positions. The nature and throw of the thrust fault to the southeast of the city of 
Table 2 Hydraulic and thermal properties of the Paleozoic formations

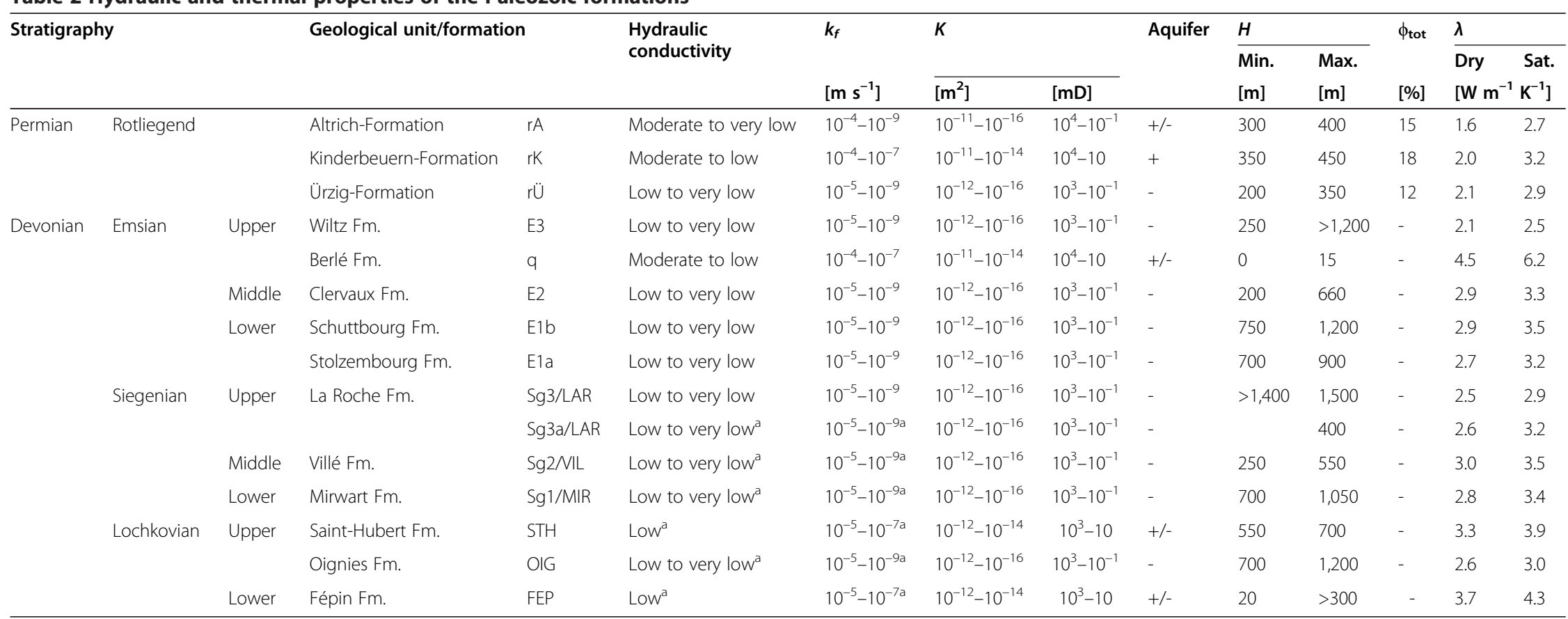

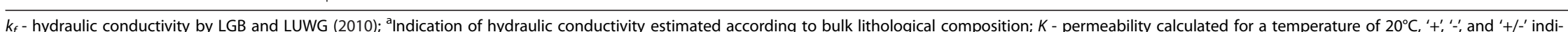
cate whether a unit is known, not known, or partly known to have aquifer quality, respectively; $H$ - common thickness range, $\phi_{\text {tot }}$ - total porosity, $\lambda$ - thermal conductivity in dry (Dry) and water-saturated (Sat.) conditions. Thickness, porosity, and thermal conductivity values by Schintgen et al. (2015). For the Rotliegend formation, thickness and thermal conductivity are based on data by Häfner et al. (2007). 

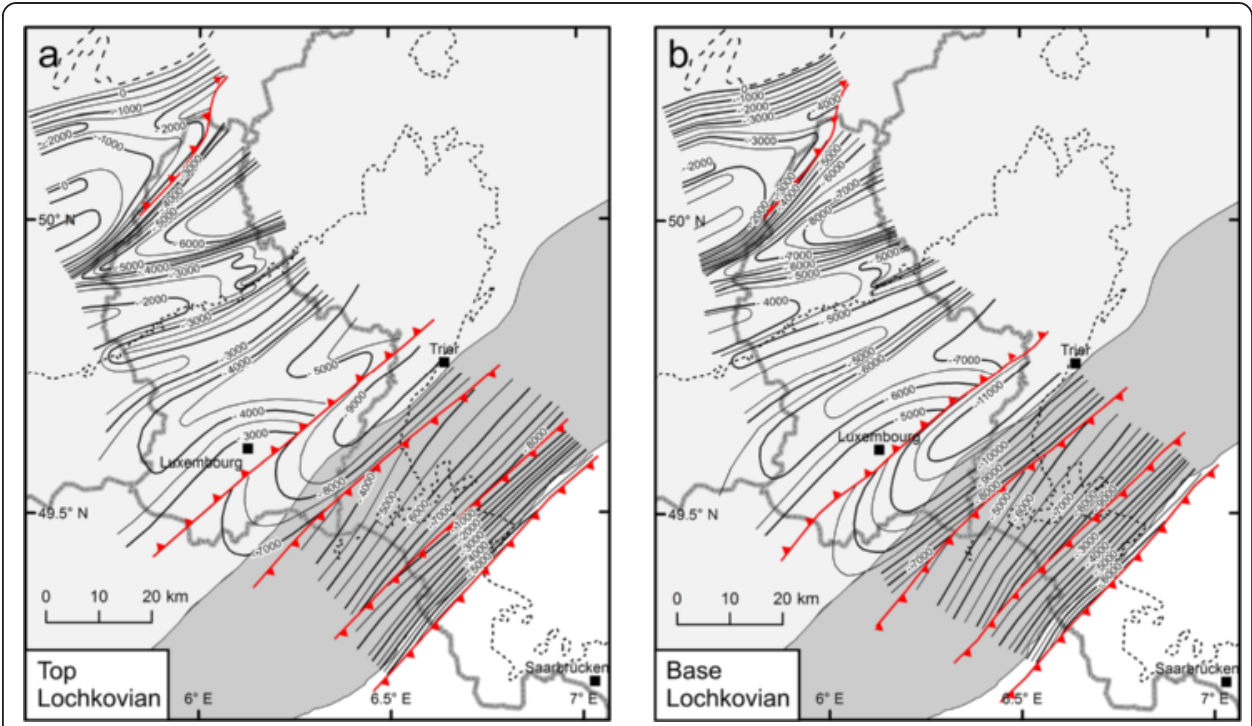

Figure 9 Geometry of the Lochkovian succession. (a) Top and (b) base. Depth in meters below mean sea level. Gray and light gray zones indicate the Hunsrück and Ardennes-Eifel blocks, respectively.

Luxembourg (i.e., the Luxembourg Fault and its prolongation at depth) is particularly uncertain. In the Hunsrück region in Germany, the Taunusquarzit of Middle to Upper Siegenian (Praguian) age consists mainly of highly fractured quarzitic sandstone and hosts, together with the overlying Dhrontal-Schichten, the waterhead of numerous streams (Wildberger 1992). It has a minimum thickness of about 1,000 m (Wildberger 1992; Stets and Schäfer 2011). Due to complex tectonics and apparent facies changes (Meyer and Stets 1996; Stets and Schäfer 2002, 2011) the possible northwestern extension of the Taunusquarzit into the Eifel region remains unknown (e.g., Wierich 1999; Wildberger 1992; Zitzmann et al. 1987).

Hydrogeology of the Lochkovian in the Ardennes The depth position of the Lochkovian sediments in the geological and structural context is presented in Figure 10 with a twofold exaggeration. The Fépin Formation at the base of the Lochkovian unconformably overlies the Caledonian basement (Cambrian-Ordovician). It is dominated by coarse to gravelly sandstones and conglomerates (Bultynck and Dejonghe 2001; Dejonghe 2008). To the south of the Stavelot Massif, a transitional facies predominantly containing shales and siltstones and subordinate gravelly to conglomeratic sandstone prevails. Due to its transgressional character, the thickness presents a wide range of tens of meters to several hundreds of meters (Dejonghe 2008). If a correlation with the similar Bunte Schiefer at the southern border of the Hunsrück (LGB 2005; Stets and Schäfer 2002) is considered, the Fépin Formation may reach an even greater thickness. As an evidence of local aquifer quality at the southern border of the Stavelot Massif, springs occur in the Lower Devonian quartzitic sandstone and conglomerate at the contact with the underlying impermeable Caledonian rocks. The overlying Oignies Formation also contains sandstone beds. The Saint-Hubert Formation at the top of the Lochkovian locally contains massive lenses of quartzitic sandstone which is mined in large quarries (Dejonghe 2008). However, the lack of deep boreholes in the Lower Devonian in the centre of the Rhenohercynian basin precludes further knowledge 


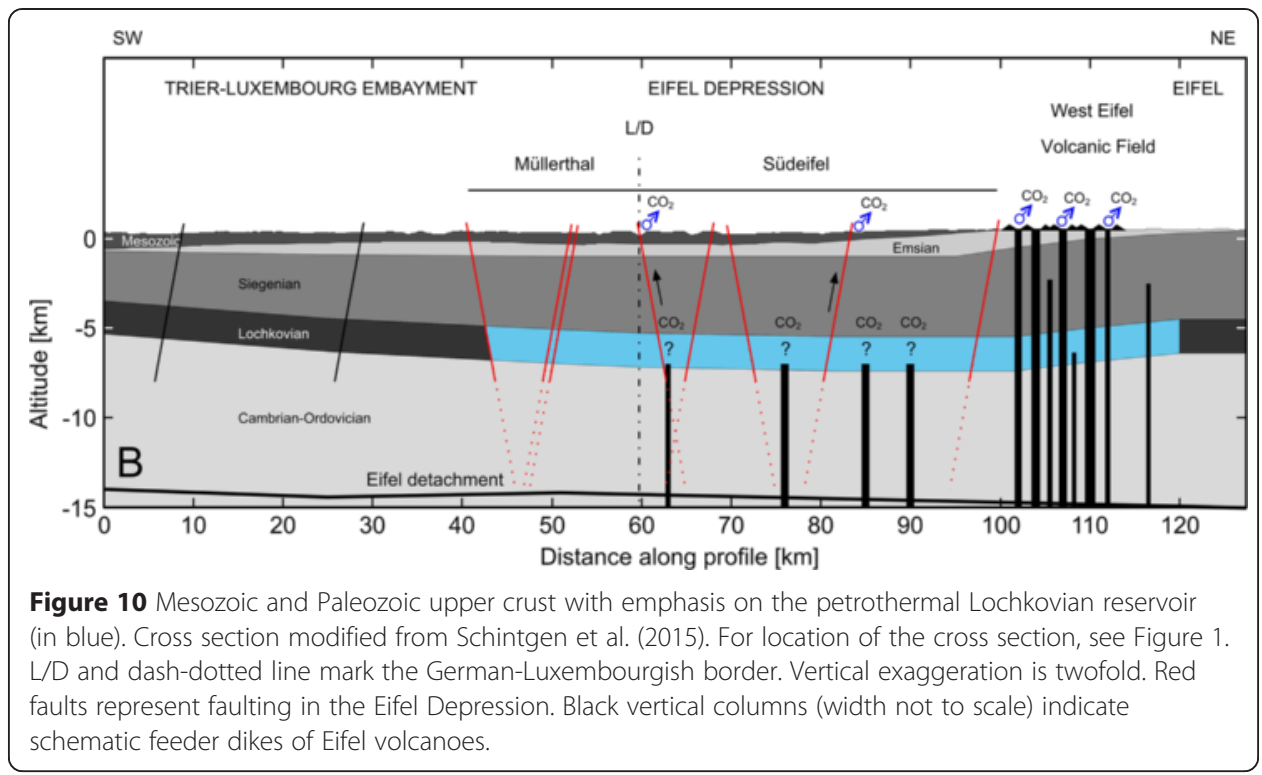

on the distribution of lithologies, thicknesses, and extent of surface formations at depth (Stets and Schäfer 2002, 2011). However, parallelization with the Belgian Ardennes suggests that the known Lower Devonian formations and their lateral equivalents extend southeastwards in the subsurface of Luxembourg and the western margin of the Eifel region. The total thickness of Lochkovian formations is in the range of 1,300 to 2,500 m (Table 2).

Measured porosity of the Lower Devonian rock samples generally is very low (1\% to 4\%; average about 3\%; Schintgen et al. 2015), but fracture porosity/permeability of sandstone/quartzite formations is known from exposure (Wildberger 1992). According to Lorenz $(2003,2007)$, hard rocks in the Eifel region are transected by joints and faults which frequently are hydraulically conductive. Further evidence that migration of fluids is generally possible in the Ardennes and the Eifel is the occurrence of numerous veintype ore deposits (Dejonghe 1998; Meyer 1994; Philippo 2007). Permeability of the Lower Devonian derived from LGB and LUWG (2010) is in the range of $10^{-12}$ to $10^{-16} \mathrm{~m}^{2}$. Under those conditions and the size of the hydraulic system, convection is generally possible (Manning and Ingebritsen 1999), thus theoretically enabling the possibility of advective coupled fluid and heat flow. Consequently, convection-driven heat advection may be more efficient then heat conduction (Clauser 2009; Deming et al. 1992; Deming 1994; Manning and Ingebritsen 1999; Smith and Chapman 1983). This may challenge the purely conductive thermal model presented by Schintgen et al. (2015). Furthermore, in situ permeability depends on the amount and type of dissolved solids, pressure, gas content, and temperature (Stober et al. 2009). Strong $\mathrm{CO}_{2}$ degassing occurs at the intersection of the WEVF and ED (Figure 10; Griesshaber et al. 1992; Schmincke 2007). In Figure 10, sources of $\mathrm{CO}_{2}$ in the South Eifel and West Eifel regions are schematically shown as vertical magmatic dikes. Arrows indicate ascent of $\mathrm{CO}_{2}$-rich water to the mineral springs at the surface. According to Schmincke (2007), the ED represents a lithosphere-scale weakness zone which apparently increased the volcano density, and influenced the distribution (fissure direction) and composition (xenolith types) of volcanism in the WEVF. In particular, more than 50 sites of mineral springs associated with $\mathrm{CO}_{2}$ degassing are found in the 
South Eifel region, the West Eifel, and the Moselle valley (Langguth and Plum 1984; Lucius 1959; Wagner et al. 2012; Werle 2009). The springs are often located at the intersection of valleys and deep-reaching faults. Natural productivity of tapped springs is about $10 \mathrm{l} \mathrm{s}^{-1}$. The highest measured spring temperatures are known in the Moselle valley to the south of the WEVF ( $>30^{\circ} \mathrm{C}$; Langguth and Plum 1984). In general, however, mineral waters known at the surface are relatively cool, no particularly high heat flow due to the young volcanism in the WEVF was observed (Langguth and Plum 1984; Griesshaber et al. 1992; LGB and LUWG 2010). Groundwater from surface manifestations in the Lower Devonian is poorly mineralized (up to $4 \mathrm{~g} \mathrm{l}^{-1}$ ) but aggressive due to its content in carbonic acid (up to $3 \mathrm{~g} \mathrm{l}^{-1}$ ) (Griesshaber et al. 1992; Lucius 1953, 1959). Mineralization of deeper reservoirs might be higher but so far remains unknown. The origin of $\mathrm{CO}_{2}$ is local and bound to the presence of groundwater (Lucius 1959; Meyer and Stets 1996). This suggests that large-scale groundwater circulation is possible underneath the South Eifel area and that the $\mathrm{CO}_{2}$ is related to the cooling magma due to unsuccessful attempts of smallvolume magma batches to erupt on the surface (Figure 10; Bräuer et al. 2013; Langguth and Plum 1984; Lucius 1959; Schmincke 2007). Furthermore, recent tectonic mobility (see 'Cenozoic structural evolution of the Müllerthal-Südeifel Depression' subsection), deep magma emplacement and $\mathrm{CO}_{2}$ degassing are related to the fact that the South Eifel area is located above the western margin of the Eifel plume (Bräuer et al. 2013; Keyser et al. 2002; Seiberlich et al. 2013; Walker et al. 2005). The fact that the adjoining Müllerthal region in Luxembourg, which also lies within the ED, does not have any mineral springs may be related to the relatively thick and impermeable sedimentary cover and a lower number of faults.

\section{Geothermal reservoirs}

Hydrothermal reservoirs

Buntsandstein The temperature distribution at the base of the Buntsandstein based on the thermal data by Schintgen et al. (2015) is shown in Figure 11. If the possibility of convection and advective heat transport by fluid flow in the Buntsandstein aquifer is excluded, temperatures are related to depth, thus thickness of the sedimentary cover, and the thermal gradient. The latter depends on the thermal conductivities of the overlying formations (Table 1) and the regional surface heat flow. The lowest temperature of about $10^{\circ} \mathrm{C}$ (mean annual surface temperature) is encountered along the margins of the TLE where the Buntsandstein aquifer is exposed. The highest temperatures of about $50^{\circ} \mathrm{C}$ are expected in the most southern part of Luxembourg in the LuxembourgishFrench border region. The Bois-châté borehole in northern Lorraine provided about $50^{\circ} \mathrm{C}$ warm water, while temperatures in the range of $36^{\circ} \mathrm{C}$ to $42^{\circ} \mathrm{C}$ were recorded in Amnéville (Am in Figure 8) (C. Dezayes, personal communication). A 'top down' approach can be used to calculate temperatures in the subsurface up to several kilometers depth by applying the Fourier equation of heat conduction:

$$
q=-\lambda \cdot \frac{d T}{d z}
$$

where $q$ is the surface heat flow (in $\mathrm{mW} \mathrm{m}^{-2}$ ), $\lambda$ is the TC of a geological unit (in W $\mathrm{m}^{-1} \mathrm{~K}^{-1}$ ), and $d T / d z$ is the thermal gradient within each geological unit (in $\mathrm{K} \mathrm{km}^{-1}$ ). 


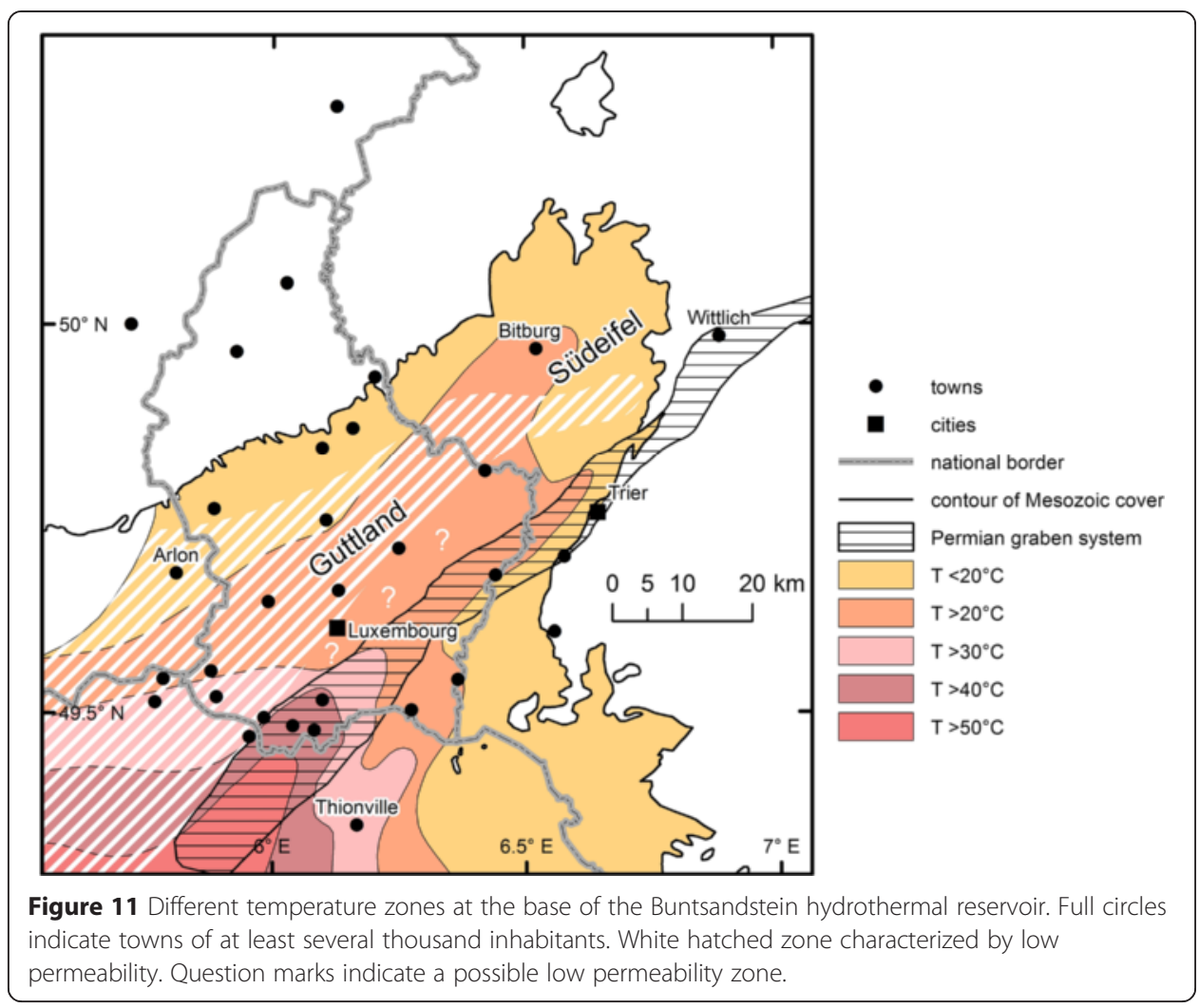

The thermal gradient corresponds to the temperature difference $d T$ (in ${ }^{\circ} \mathrm{C}=\mathrm{K}-273$ ) at the top and base of each unit divided by the thickness $d z$ (in $\mathrm{m}$ ) of the unit. Temperatures of about $36^{\circ} \mathrm{C}$ to $42^{\circ} \mathrm{C}$ at the top and base of the Buntsandstein aquifer, respectively, were calculated in the southern part of the Alzette valley where the Buntsandstein reaches a maximum depth of about $850 \mathrm{~m}$ (top) and 1,100 m (base) below surface. Just to the south of the city of Luxembourg, in the northern part of the upper Alzette valley, where the top and base are located in about 600 and $850 \mathrm{~m}$ depth, respectively, inferred temperatures amount to about $27^{\circ} \mathrm{C}$ to $33^{\circ} \mathrm{C}$. As a result, the warmest part of the Buntsandstein aquifer coincides with the region where it lies below the Liassic cover, more specifically the part of the SE-Luxembourg Graben beneath the upper Alzette valley. The warm zone extends further to the south below the Dogger limestone plateau in the southernmost part of Luxembourg and the northernmost part of Lorraine (Figure 11). In consideration of the local elevation of the upper Alzette valley, the water table of the Buntsandstein aquifer is probably located 40 to $50 \mathrm{~m}$ below terrain level. The key information to the selected reservoirs is presented in Table 3. Geothermal heat for district heating is of particular interest in the highly populated southwestern part of Luxembourg and the capital of Luxembourg (Figure 11), making up $60 \%$ of the total population in 2014 (canton of Esch: 161,000; canton of Luxembourg: 167,000; STATEC 2014). However, since the temperatures are $<60^{\circ} \mathrm{C}$ in the Buntsandstein aquifer, heat pumps have to be used to allow space and district heating (Bujakowski and Barbacki 2004; Líndal 1973). In the warmest and most permeable zones in the southeastern part of the TLE, minimum $k_{f}$ values of $5 \times 10^{-5} \mathrm{~m} \mathrm{~s}^{-1}$ are attained for successful exploitation of hydrothermal reservoirs according to Stober 
Table 3 Major hydrothermal and petrothermal reservoirs

\begin{tabular}{|c|c|c|c|c|}
\hline Stratigraphy & $\begin{array}{l}\text { Mesozoic } \\
\text { Buntsandstein }\end{array}$ & $\begin{array}{l}\text { Permian } \\
\text { Rotliegend }\end{array}$ & $\begin{array}{l}\text { Devonian } \\
\text { Upper+Middle } \\
\text { Siegenian }\end{array}$ & $\begin{array}{l}\text { Devonian } \\
\text { Lochkovian }\end{array}$ \\
\hline Region & $\begin{array}{l}\text { Trier-Luxembourg } \\
\text { Embayment }\end{array}$ & $\begin{array}{l}\text { SE-Luxembourg Graben } \\
+ \text { Wittlicher Senke }\end{array}$ & $\begin{array}{l}\text { Hunsrück (+Mosel } \\
\text { region?) }\end{array}$ & Ardennes (+NW Eifel?) \\
\hline Formations & $\begin{array}{l}\text { Voltziensandstein } \\
\text { +Zwischenschichten } \\
\text { +Vogesensandstein }\end{array}$ & $\begin{array}{l}\text { Altrich+Kinderbeuern } \\
+ \text { Ürzig }\end{array}$ & Taunusquarzit & $\begin{array}{l}\text { Saint-Hubert+Oignies } \\
\text { +Fépin }\end{array}$ \\
\hline $\begin{array}{l}\text { Reservoir } \\
\text { lithotype }\end{array}$ & $\begin{array}{l}\text { Sandstone+ } \\
\text { conglomerate }\end{array}$ & $\begin{array}{l}\text { Sandstone+breccia/ } \\
\text { conglomerate }\end{array}$ & Quartzite & Sandstone+quartzite \\
\hline Reservoir type & Hydrothermal & $\begin{array}{l}\text { Hydrothermal/ } \\
\text { petrothermal }\end{array}$ & Petrothermal & Petrothermal \\
\hline Depth [m] & 0 to 1,200 & 0 to 2,500 & 0 to 4,000 & 3,500 to 6,000 \\
\hline Thickness [m] & 150 to 300 & $>1,000$ & $>1,000$ & 1,300 to 2,500 \\
\hline$T\left[{ }^{\circ} \mathrm{C}\right]$ & 10 to 50 & 10 to 75 & 10 to 90 & 90 to 140 \\
\hline$k_{f}\left[\mathrm{~m} \mathrm{~s}^{-1}\right]$ & $10^{-4}$ to $10^{-7}$ & $10^{-4}$ to $10^{-9}$ & $10^{-5}$ to $10^{-7}$ & $10^{-5}$ to $10^{-7}$ \\
\hline
\end{tabular}

$T$ - temperature, $k_{f}$ - hydraulic conductivity.

et al. (2009). In Mondorf, hydraulic conductivities measured (Leichtle 1980) are 10 to 50 times lower, but the corresponding average transmissibility with an about 240-mthick Buntsandstein amounts to $24 \mathrm{Dm}$. According to Van Wees et al. (2012), transmissibilities $>30 \mathrm{Dm}$ are an excellent property of natural aquifers for geothermal energy use. Total mineralization also is comparatively low (12 to $\left.23 \mathrm{~g} \mathrm{l}^{-1}\right)$ and suitable for hydrothermal energy use.

Rotliegend In the considered zone of the SELG beneath the upper Alzette valley, the inferred Rotliegend graben below the Buntsandstein aquifer may reach a maximum depth of about 2,000 $\mathrm{m}$ in the northeast in the vicinity of the city of Luxembourg and $2,500 \mathrm{~m}$ in the southwest in the Luxembourgish-French border region associated with calculated temperatures of about $63^{\circ} \mathrm{C}$ and $75^{\circ} \mathrm{C}$ at the base of the graben, respectively. A summary of relevant information is listed in Table 3. Geological and geophysical exploration is clearly needed to assess subsurface conditions (geology, structure, permeability, mineralization, temperature) in the inferred Rotliegend graben. Exploration data would shed light on the possibilities of direct use for space heating and cooling.

\section{Petrothermal reservoirs}

Lower Devonian In the subsurface of Luxembourg and the surrounding areas, temperatures $>120^{\circ} \mathrm{C}$ and appropriate for efficient use in binary power plants are reached at depths $>5,000 \mathrm{~m}$ (below mean sea level; see Figure 4; Schintgen et al. 2015). Figure 12 shows the temperatures expected at the top of the Lochkovian, i.e., the Saint-Hubert Formation. The top of the sandstone-/quartzite-rich, approximately 1,000 to 2,000-mthick Lochkovian formations is reached at depths $>3,000 \mathrm{~m}$ in the west and $>5,000 \mathrm{~m}$ in the east (see Figure 9a). As the thermal gradient within the Lower Devonian amounts to about $20^{\circ} \mathrm{C} \mathrm{km}^{-1}$, the temperature pattern shown in Figure 12 is directly related to the depth of the Lochkovian. In the Hunsrück region, another possible petrothermal reservoir with a thickness $>1,000 \mathrm{~m}$ is the Taunusquarzit. However, the northwestward extension of the Taunusquarzit beyond the Hunsrück region where 


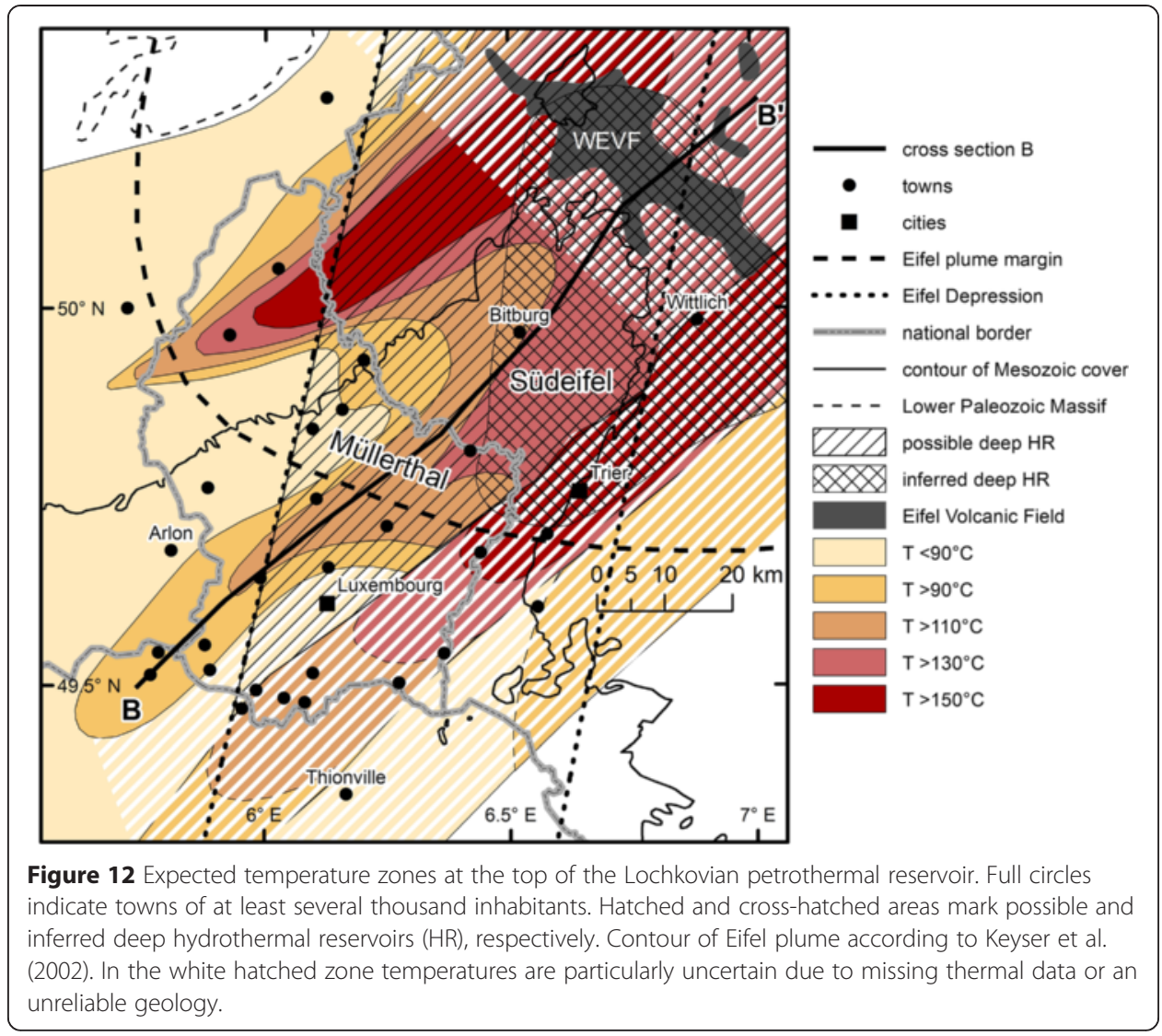

temperatures are best suited for EGS $\left(>120^{\circ} \mathrm{C}\right.$ at 5,000 m) remains unknown. Table 3 summarizes key information including ranges of depth, thickness, temperature, and hydraulic conductivity for different petrothermal reservoirs.

A crucial factor in the production of geothermal energy is related to the large uncertainty of effective porosity/permeability and transmissivity/transmissibility values, which directly influence the achievable flow rates and thus doublet power in petrothermal systems (e.g., Schulte et al. 2010). Actively deforming areas characterized by extensional and strike-slip settings are favorable for EGS (Cloetingh et al. 2010). Furthermore, Garnish (2002) points out that the natural fracture system largely dominates induced fractures. Although the tectonic regime in the TLE is compressional at the surface (Dittrich 2014), it most likely evolves towards a strike-slip regime with increasing depth under the weight of a sufficient overburden. As a positive aspect of the region of Luxembourg and the South Eifel, it may be considered that historical seismicity and present-day microearthquake activity related to the geodynamical processes in the RM is low (Ahorner 1983; Cloetingh et al. 2009; Ziegler and Dèzes 2007). The MSD, which corresponds to a zone of relatively high temperature $\left(>120^{\circ} \mathrm{C}\right.$ at $\left.5,000 \mathrm{~m}\right)$, is likely characterized by a tectonically enhanced transmissibility and may therefore represent a deep hydrothermal reservoir. Deep fluid downflow preferentially along fault zones in the Eifel region (Lorenz 2003, 2007) is a requirement to explain the origin of the hot springs in Aachen (Bayer et al. 1996; Langguth and Plum 1984; Pommerening 1993). The entire zone of mineral springs in and around the South Eifel region might be the clearest indication of a hydrothermal reservoir at depth. If permeability of the 
Lochkovian formations is assumed to be low (ranging to $10^{3}$ to $10 \mathrm{mD}$ according to LGB and LUWG 2010), and an effective thickness of $500 \mathrm{~m}$ is adopted, i.e., $50 \%$ to $25 \%$ of the total thickness of the Lochkovian rock, the resulting transmissibility is in the range of 500 to $5 \mathrm{Dm}$. In contrast to petrothermal systems, this span in transmissibility would characterize a hydrothermal system ( $>5 \mathrm{Dm}$ ) according to Stober et al. (2009). However, the highest permeabilities are expected in tectonically active regions. Therefore, the zone of the ED and the MSD probably yield a higher productivity.

\section{Conclusions}

This paper aimed at combining different types of information necessary for a first rather qualitative assessment of deep geothermal reservoirs in Luxembourg and the adjoining regions in the surrounding countries of Belgium, France, and Germany. Hydrothermal and petrothermal reservoirs were considered. Hydrothermal resources with temperatures up to $50^{\circ} \mathrm{C}$ for use by means of heat pumps or direct use are found in the Buntsandstein aquifer. The most promising area is the part of the SELuxembourg Graben located below the Liassic cover, more specifically under the upper Alzette River valley. At the base of an inferred Rotliegend graben in the same zone, temperatures up to $75^{\circ} \mathrm{C}$ are expected. However, geological and hydraulic conditions are largely unknown. Expected sandstone-/quartzite-rich formations in the Lochkovian towards the base of the Lower Devonian in the Ardennes-Eifel block offer the possibility of widespread use of EGS technology, despite a moderate temperature gradient of about $20^{\circ} \mathrm{C}$ in the Paleozoic basement. Based on recent data on the structure of the Trier-Luxembourg Basin, the new concept of the Müllerthal-Südeifel Depression is presented as a Cenozoic tectonic structure which is still mobile and potentially hydraulically conductive. The Müllerthal-Südeifel Depression therefore represents a particular target region for future geothermal exploration and implementation of EGS. In addition, numerous mineral springs with high $\mathrm{CO}_{2}$ content in the WEVF and the South Eifel region suggest the existence of a large hydrothermal reservoir at a depth of several kilometers. Expected temperatures are at least $120^{\circ} \mathrm{C}$ to $125^{\circ} \mathrm{C}$ at $5 \mathrm{~km}$ depth. In the most permeable zones, both in the Buntsandstein and the Lochkovian, the span of hydraulic conductivities varies approximately within a factor 100 . Hydraulic conductivity therefore is a crucial parameter for determining flow rates and thus power output of a geothermal plant. The current lack of deep exploration boreholes and geophysical data emphasizes the need for substantially more research, development, and demonstration funding (RD\&D) for geothermal exploration, resource assessment, and potential exploitation of geothermal energy for base-load electricity generation and provision of heating and/or cooling.

\footnotetext{
Abbreviations

ACT: Administration du Cadastre et de la Topographie; BRGM: Bureau de Recherches Géologiques et Minières; ECRIS: European Cenozoic Rift System; ED: Eifel Depression; EGS: Enhanced/Engineered Geothermal Systems; GFZ: Helmholtz Centre Potsdam-GFZ Gerrman Research Centre for Geosciences; HDR: hot-dry rock systems; LGB: Landesamt für Geologie und Bergbau Rheinland-Pfalz; LRG: Lower Rhine Graben; LUWG: Landesamt für Umwelt, Wasserwirtschaft und Gewerbeaufsicht Rheinland-Pfalz; MSD: Müllerthal-Südeifel Depression; ORC: organic rankine cycle; R\&D: research and development; RD\&D: research, development, and demonstration; RM: Rhenish Massif; SELG: SE-Luxembourg Graben; STATEC: Institut national de la statistique et des études économiques du Grand-Duché du Luxembourg; TC: thermal conductivity; TLB: Trier-Luxembourg Basin; TLE: Trier-Luxembourg Embayment; URG: Upper Rhine Graben; WEVF: West Eifel volcanic field; WS: Wittlicher (Rotliegend) Senke.
} 


\section{Author's contribution}

TS wrote the article, prepared the figures, and set up the tables. TS also developed the conceptual models which are used here to reconstruct the regional geological evolution of the Müllerthal-Südeifel region.

\section{Author's information}

TS is currently a doctoral candidate at the Helmholtz Centre Potsdam-GFZ Gerrman Research Centre for Geosciences. TS also is a board member of the AGL Association Géologique du Luxembourg.

\section{Acknowledgements}

This paper forms part of the doctoral thesis of TS entitled 'The Geothermal Potential of Luxembourg'. The project is supported by the National Research Fund (Luxembourg) via an AFR research grant under the reference 866943 and the GFZ German Research Centre for Geosciences (Potsdam, Germany). The author would like to thank Dr. Andrea Förster (GFZ Potsdam) for critical comments which helped to improve the manuscript. Constructive reviews by two anonymous reviewers helped to significantly improve the manuscript and are gratefully acknowledged.

Received: 9 March 2015 Accepted: 22 April 2015

Published online: 13 June 2015

\section{References}

ACT (Administration du Cadastre et de la Topographie) (2014) Geoportal of the Grand-Duchy of Luxembourg., http:// map.geoportail.lu/?lang=en. Accessed: 11 May 2015

Ahorner L (1983) Historical seismicity and present-day microearthquake activity of the Rhenish Massif, Central Europe. In: Fuchs K, von Gehlen K, Mälzer H, Murawski H, Semmel A (eds) Plateau Uplift: The Rhenish Shield - A Case History. Springer, Berlin, Heidelberg, New York, Tokyo, pp 198-221

Bär K, Arndt D, Fritsche J-G, Götz AE, Kracht M, Hoppe A, Sass I (2011) 3D-Modellierung der tiefengeothermischen Potenziale von Hessen - Eingangsdaten und Potenzialausweisung. Z Dt Ges Geowiss 162:371-388

Bayer U, Lünenschloß B, Springer J, von Winterfeld C (1996) Thermal modeling at an ancient orogenic front with special regard to the uncertainty of heat-flow predictions. In: Förster A, Merriam DF (eds) Geologic Modeling and Mapping. Plenum Press, New York, pp 79-93

Berckmans A, Vandenberghe N (1998) Use and potential of geothermal energy in Belgium. Geothermics 27:235-242

Biermayr P, Cremer C, Faber T, Kranzl L, Ragwitz M, Resch G, Toro F (2007) Bestimmung der Potenziale und Ausarbeitung von Strategien zur verstärkten Nutzung von erneuerbaren Energien in Luxemburg. Endbericht, Fraunhofer Institut für System- und Innovationsforschung (Fh-ISI), Karlsruhe, Energy Economics Group (EEG), TU Wien, BSR-Sustainability, Karlsruhe

Bintz J (2000) Le paysage géologique de Mondorf et la géologie de ses forages-captages. In: Gerges M (ed) Mondorf le domaine thermal: Mondorf - son passé, son présent, son avenir. Les publications mosellanes, Le domaine thermal, Mondorf, pp 313-320

Bintz J (2003) Géologie et hydrogéologie de la solution de rechange pour l'alimentation en eau potable du pays lors de la vidange du lac d'Esch-sur-Sûre. Bull Soc Nat Luxemb 103:121-129

Bintz J, Frantz M, Fried JJ (1982) Bilan des ressources en eau souterraine du Grand-Duché de Luxembourg. CECA, CEE, CEEA, Bruxelles-Luxembourg

Bonté D, Guillou-Frottier L, Garibaldi C, Bourgine B, Lopez S, Bouchot V, Lucazeau F (2010) Subsurface temperature maps in French sedimentary basins: new data compilation and interpolation. Bull Soc Geol Fr 181:377-390

Bonté D, van Wees J-D, Verweij JM (2012) Subsurface temperature of the onshore Netherlands: new temperature dataset and modelling. Neth J Geosci 91:491-515

Bourgeois O, Ford M, Diraison M, Carlier L, de Veslud C, Gerbault M, Pik R, Ruby N, Bonnet S (2007) Separation of rifting and lithospheric folding signatures in the NW-Alpine foreland. Int J Earth Sci 96:1003-1031

Bourgine B, Denis L, Filhine-Tressarrieu T, Monnot P, Nguyen-Thé D, Robelin C (2007) Atlas du potentiel géothermique des aquifères lorrains. Rapport BRGM/RP-54987-FR, Orléans, http://www.geothermie-perspectives.fr/sites/default/ files/rp 54987 fr.pdf. Accessed 11 May 2015

Bräuer K, Kämpf H, Niedermann S, Strauch G (2013) Indications for the existence of different magmatic reservoirs beneath the Eifel area (Germany): a multi-isotope (C, N, He, Ne, Ar) approach. Chem Geol 356:193-208

Breede K, Dzebisashvili K, Liu X, Falcone G (2013) A systematic review of enhanced (or engineered) geothermal systems: past, present and future. Geothermal Energy. doi:10.1186/2195-9706-1-4

BRGM (Bureau de Recherches Géologiques et Minières) (2015) Dossier du sous-sol (BSS) http://infoterre.brgm.fr Accessed 11 May 2015

Bujakowski W, Barbacki A (2004) Potential for geothermal development in Southern Poland. Geothermics 33:383-395

Bultynck P, Dejonghe $L$ (2001) Devonian lithostratigraphic units (Belgium). In: Bultynck P, Dejonghe $L$ (eds) Guide to a revised lithostratigraphic scale of Belgium, vol 4(1-2). Geologica Belgica, Brussels, pp 39-69

Celle-Jeanton H, Huneau F, Travi Y, Edmunds WM (2009) Twenty years of groundwater evolution in the Triassic sandstone aquifer of Lorraine: impacts on baseline water quality. Appl Geochem 24:1198-1213

Clauser C (2009) Heat transport processes in the Earth's crust. Surv Geophys 30:163-191. doi:10.1007/s10712-009-9058-2

Cloetingh S, Thybo H, Faccenna C (2009) TOPO-EUROPE: studying continental topography and deep earth-surface processes in 4D. Tectonophysics 474:4-32

Cloetingh S, van Wees JD, Ziegler PA, Lenkey L, Beekman F, Tesauro M, Förster A, Norden B, Kaban M, Hardebol N, Bonté D, Genter A, Guillou-Frottier L, Ter Voorde M, Sokoutis D, Willingshofer E, Cornu T, Worum G (2010) Lithosphere tectonics and thermo-mechanical properties: an integrated modelling approach for Enhanced Geothermal Systems exploration in Europe. Earth Sci Rev 102:159-206

Coiffait B, Ricour J (1982) Forages aux Grès du Trias inférieur en Lorraine, analyse des archives disponibles, propositions pour une amélioration de la technologie de réalisation et d'équipement. BRGM, Serv Géol Rég Lorraine, Vandoeuvre 
Dejonghe L (1998) Zinc-lead deposits of Belgium. Ore Geol Rev 12:329-354

Dejonghe L (2008) Carte géologique de Wallonie 1/25.000, feuille 55/5-6 Hotton-Dochamps. Notice explicative, Région Wallonne, Namur

Deming D (1994) Fluid flow and heat transport in the upper continental crust. In: Parnell J (ed) Geofluids: Origin Migration and Evolution of Fluids in Sedimentary Basins, vol 78. Geol Soc Spec Publ, London, pp 27-42

Deming D, Sass JH, Lachenbruch AH, De Rito RF (1992) Heat flow and subsurface temperature as evidence for basinscale ground-water flow, North Slope of Alaska. Geol Soc Amer Bull 104:528-542

Demoulin A, Hallot E (2009) Shape and amount of the Quaternary uplift of the western Rhenish shield and the Ardennes (western Europe). Tectonophysics 474:696-708

Dèzes P, Schmid SM, Ziegler PA (2004) Evolution of the European Cenozoic Rift System: interaction of the Alpine and Pyrenean orogens with their foreland lithosphere. Tectonophysics 389:1-33

Dittrich D (1989) Beckenanalyse der Oberen Trias der Trier-Luxemburger Bucht. Revision der stratigraphischen Gliederung und Rekonstruktion der Paläogeographie, vol 26. Publ Serv Géol Lux, Luxembourg

Dittrich D (2008) Schertektonik im triassischen Deckgebirge der nordwestlichen Trierer Bucht - Teil I. Mainzer geowiss Mitt 36:69-104

Dittrich D (2009) Schertektonik im triassischen Deckgebirge der nordwestlichen Trierer Bucht - Teil II. Mainzer geowiss Mitt 37:77-128

Dittrich D (2011) Schertektonik im triassischen Deckgebirge der südöstlichen Trier-Luxemburger Bucht - Teil I. Mainzer geowiss Mitt 39:7-86

Dittrich D (2012) Schertektonik im mesozoischen Deckgebirge der südöstlichen Trier-Luxemburger Bucht - Teil II. Mainzer geowiss Mitt 40:79-146

Dittrich D (2013) Schertektonik im mesozoischen Deckgebirge der südöstlichen Trier-Luxemburger Bucht - Teil III. Mainzer geowiss Mitt 41:123-212

Dittrich D (2014) Schertektonik im mesozoischen Deckgebirge der südöstlichen Trier-Luxemburger Bucht - Teil IV. Mainzer geowiss Mitt 42:27-98

Dittrich D (with contributions by Gad J, Schäfer P, Weidenfeller M) (2011) Geologische Karte der Trierer Bucht 1:50000 mit Erläuterungen. Landesamt für Geologie und Bergbau Rheinland-Pfalz, Mainz

ENGINE Coordination Action (2008) Best practice handbook for the development of unconventional geothermal resources with a focus on Enhanced Geothermal System 2008. Collection Actes/Proceedings, BRGM, Orléans, http:// engine.brgm.fr/Documents/ENGINE_BestPracticeHandbook.pdf. Accessed 11 May 2015

Fuchs K, von Gehlen K, Mälzer H, Murawski H, Semmel A (eds) (1983) Plateau uplift: the Rhenish Shield - a case history. Springer, Berlin, Heidelberg, New York, Tokyo

Garnish J (2002) European activities in hot dry rock research. In: Open Meeting on Enhanced Geothermal Systems. US Department of Energy, Reno/NV, September 26th to 27th 2002. http://geothermal.smu.edu. Accessed 6 Feb 2015

Griesshaber E, O'Nions RK, Oxburgh ER (1992) Helium and carbon isotope systematics in crustal fluids from the Eifel, the Rhine Graben and Black Forest, FRG. Chem Geol 99:213-235

Häfner F, Kött A, Spindeldreher J, Rein B, Grubert A (2007) Nutzung von oberflächennaher Erdwärme für die Gebäudeheizung in Rheinland-Pfalz. Bericht, Landesamt für Geologie und Bergbau Rheinland-Pfalz, Mainz

Held S, Genter A, Kohl T, Kölbel T, Sausse J, Schoenball M (2014) Economic evaluation of geothermal reservoir performance through modeling the complexity of the operating EGS in Soultz-sous-Forêts. Geothermics 51:270-280

Huenges E (ed) (2010) Geothermal Energy Systems: exploration, development, and utilization. Wiley-VCH, Berlin

International Energy Agency (IEA) (2011) Technology roadmap geothermal heat and power. OECD/IEA, Paris, http:// www.iea.org/publications/freepublications/publication/Geothermal_Roadmap.pdf. Accessed 11 May 2015

Kaltschmitt M, Huenges E, Wolff H (eds) (1999) Energie aus Erdwärme. Deutscher Verlag für Grundstoffindustrie (DVG), Stuttgart

Keyser M, Ritter JRR, Jordan M (2002) 3D shear-wave velocity structure of the Eifel plume, Germany. Earth Planet Sci Lett 203:59-82

Kramers L, van Wees J-D, Pluymaekers MPD, Kronimus A, Boxem T (2012) Direct heat resource assessment and subsurface information systems for geothermal aquifers; the Dutch perspective. Neth J Geosci 91:637-649

Kremb-Wagner F (1996) Zur Geologie und Hydrogeologie der Trier-Bitburger Mulde. Schriftenr Schiefer-Fachverb Deutschl, Sonderband, Bonn, pp 1-130

Kremb-Wagner F, Negendank JWF, Wagner HW (2014) Zur Struktur der Trier-Bitburger Mulde, der Fortsetzung des Trier-Wittlicher-Rotliegend-Grabens und weiterer Strukturen. Z Dt Ges Geowiss 165(3):367-372

Langguth H-R, Plum H (1984) Untersuchung der Mineral- und Thermalquellen der Eifel auf geothermische Indikationen. Forschungsbericht, BMFT-FB-T 84-019, Technologische Forschung und Entwicklung Nichtnukleare Energietechnik, Lehr- und Forschungsgebiet für Hydrogeologie der RWTH Aachen, Bundesministerium für Forschung und Technologie, Bonn

Ledru P, Guillou-Frottier L (2010) Reservoir definition. In: Huenges E (ed) Geothermal Energy Systems: exploration, development, and utilization. Wiley-VCH, Berlin, pp 1-36

Leichtle T (1980) Die Thermalwassertiefbohrung Michel-Lucius. Bericht, Bad Mondorf, Luxemburg

LGB (Landesamt für Geologie und Bergbau Rheinland-Pfalz) (ed) (2005) Geologie von Rheinland-Pfalz. Schweizerbart, Stuttgart

LGB and LUWG (Landesamt für Geologie und Bergbau Rheinland-Pfalz, Landesamt für Umwelt, Wasserwirtschaft und Gewerbeaufsicht Rheinland-Pfalz) (ed) (2010) Hydrogeologische Kartierung Bitburg-Trier. LGB \& LUWG, Mainz

Líndal B (1973) Industrial and other applications of geothermal energy. In: Geothermal Energy. Review of Research and Development, LC No. 72-97138. UNESCO, Paris, pp 135-148

Lorenz V (2003) Maar-diatreme volcanoes, their formation, and their setting in hard-rock or soft-rock environments. Geolines 15:72-83

Lorenz V (2007) Syn- and posteruptive hazards of maar-diatreme volcanoes. J Volc Geoth Res 159:285-312

Lucius M (1923) La genèse des eaux thermo-minérales de Mondorf-les-bains. Bull Soc Nat Luxemb 1-2:3-22 
Lucius M (1948) Das Gutland. Erläuterungen zu der Geologischen Spezialkarte Luxemburgs. Publ Serv Géol Luxemb, vol 5. Service géologique du Luxembourg, Luxembourg

Lucius M (1949) La remise en état de la source thermominérale kind à Mondorf. Bull Soc belge Géol Paléont Hydrol 58:355-359

Lucius M (1953) Quelques aspects de la géologie appliquée dans l'aire de sédimentation luxembourgeoise. Publ Serv Géol Luxemb, vol 9. Service géologique du Luxembourg, Luxembourg

Lucius M (1959) Hydrogéologie de l'eau minérale carbogazeuse dite « Source de Rosport ». Revue technique luxembourgeoise 51(4):203-207

Mälzer H, Hein G, Zippelt K (1983) Height changes in the Rhenish Massif: determination and analysis. In: Fuchs K, von Gehlen K, Mälzer H, Murawski H, Semmel A (eds) Plateau uplift: the Rhenish Shield - a case history. Springer, Berlin, Heidelberg, New York, Tokyo, pp 164-176

Manning CE, Ingebritsen SE (1999) Permeability of the continental crust: implications of geothermal data and metamorphic systems. Rev Geophys 37:127-150

Meyer W (1994) Geologie der Eifel, 3rd edn. Schweizerbart, Stuttgart

Meyer W, Stets J (1996) Das Rheintal zwischen Bingen und Bonn, vol 89. Sammlung geol Führer, Borntraeger, Berlin, Stuttgart

Meyer W, Stets J (2002) Pleistocene to recent tectonics in the Rhenish Massif (Germany). Neth J Geosci 81:217-221

Muffler P, Cataldi R (1978) Methods for regional assessment of geothermal resources. Geothermics 7:53-89

Murawski H, Albers HJ, Bender P, Berners H-P, Dürr S, Huckriede R, Kauffmann G, Kowalczyk G, Meiburg P, Müller R, Muller A, Ritzkowski S, Schwab K, Semmel A, Stapf K, Walter R, Winter K-P, Zankl H (1983) Regional tectonic setting and geological structure of the Rhenish Massif. In: Fuchs K, von Gehlen K, Mälzer H, Murawski H, Semmel A (eds) Plateau uplift: the Rhenish Shield - a case history. Springer, Berlin, Heidelberg, New York, Tokyo, pp 9-38

Nicklès R (1914) Le sondage du bois-châté. Bull Soc Sci Nancy, sér III 15:197-214

Paschen H, Oertel D, Grünwald R (2003) Möglichkeiten geothermischer Stromerzeugung in Deutschland. Arbeitsbericht $\mathrm{Nr}$ 84, Deutscher Bundestag Ausschuss für Bildung, Forschung und Technikfolgenabschätzung, Berlin, https:// www.tab-beim-bundestag.de/de/pdf/publikationen/berichte/TAB-Arbeitsbericht-ab084.pdf. Accessed 11 May 2015

Philippo S (ed) (2007) Inventaire minéralogique du Luxembourg Stolzembourg, Schimpach, Goesdorf. Ferrantia, vol 49, Musée national d'histoire naturelle, Luxembourg

Pluymaekers MPD, Kramers L, van Wees J-D, Kronimus A, Nelskamp S, Boxem T, Bonté D (2012) Reservoir characterisation of aquifers for direct heat production: Methodology and screening of the potential reservoirs for the Netherlands. Neth J Geosci 91:621-636

Pommerening J (1993) Hydrogeologie, Hydrogeochemie und Genese der Aachener Thermalquellen. Mitteilungen zur Ingenieurgeologie und Hydrogeologie, vol 50. Lehrstuhl für Ingenieurgeologie und Hydrogeologie der RWTH Aachen, Aachen

Agence de l'Eau Rhin-Meuse (2002) Atlas hydrogéologique du bassin Rhin-Meuse. Moulins-lès-Metz

Rybach L (2010) 'The future of geothermal energy' and its challenges. In: proceedings of the World Geothermal Congress, International Geothermal Association, Bali, Indonesia, April 25th to 29th 2010

Saadat A, Frick S, Kranz S, Regenpurg S (2010) Energetic use of EGS reservoirs. In: Huenges E (ed) Geothermal Energy Systems: Exploration, Development, and Utilization. Wiley-VCH, Berlin, pp 303-372

Schintgen T, Förster A (2013) Geology and basin structure of the Trier-Luxembourg Basin - implications for the existence of a buried Rotliegend graben. Z Dt Ges Geowiss 164:615-637

Schintgen T, Förster A, Förster $\mathrm{H}-J$, Norden B (2015) Surface heat flow and lithosphere thermal structure of the Rhenohercynian Zone in the greater Luxembourg region. Geothermics 56:93-109

Schmincke H-U (2007) The Quaternary volcanic fields of the east and west Eifel (Germany). In: Ritter JRR, Christensen UR (eds) Mantle Plumes. A Multidisciplinary Approach. Springer, Berlin, Heidelberg, pp 241-322

Schulte T, Zimmermann G, Vuataz F, Portier S, Tischner T, Junker R, Jatho R, Huenges E (2010) Enhancing geothermal reservoirs. In: Huenges E (ed) Geothermal Energy Systems: Exploration, Development, and Utilization. Wiley-VCH, Berlin, pp 173-243

Seiberlich CKA, Ritter JRR, Wawerzinek B (2013) Topography of the lithosphere-asthenosphere boundary below the Upper Rhine Graben Rift and the volcanic Eifel region, Central Europe. Tectonophysics 603:222-236

Smith L, Chapman DS (1983) On the thermal effects of groundwater flow. J Geophys Res B88:593-608

Sperber A, Moeck I, Brandt W (2010) Drilling into geothermal reservoirs. In: Huenges E (ed) Geothermal Energy Systems: Exploration, Development, and Utilization. Wiley-VCH, Berlin, pp 113-171

STATEC (Institut national de la statistique et des études économiques du Grand-Duché du Luxembourg) (2014) Le portail des statistiques du Grand-Duché du Luxembourg., http://www.statistiques.public.lu/stat/TableViewer/ tableView.aspx?Reportld=397\&IF_Language=fra. Accessed 11 May 2015

Stets J (2004) Geologische Karte der Wittlicher Rotliegend-Senke 1:50000 mit Erläuterungen. LGB (Landesamt für Geologie und Bergbau Rheinland-Pfalz), Mainz

Stets J, Schäfer A (2002) Depositional environments in the Lower Devonian siliciclastics of the Rhenohercynian Basin (Rheinisches Schiefergebirge, W-Germany) - case studies and a model. In: Aigner T, Cross T (eds) Contr Sed Geol, vol 22. Schweizerbart, Stuttgart

Stets J, Schäfer A (2011) The Lower Devonian Rhenohercynian rift - 20 Ma of sedimentation and tectonics (Rhenish Massif, W-Germany). Z Dt Ges Geowiss 162(2):93-115

Stober I, Bucher K (2012) Geothermie. Springer, Berlin, Heidelberg

Stober I, Fritzer T, Obst K, Schulz R (2009) Nutzungsmöglichkeiten der tiefen Geothermie in Deutschland. BMU (Bundesministerium für Umwelt, Naturschutz und Reaktorsicherheit), Berlin

Storz R (2007) Tiefe Geothermie in Rheinland-Pfalz - Ein Überblick über die geothermischen Verhältnisse und den aktuellen Stand der Nutzung. Mainzer geowiss Mitt 35:135-158

Tester JW, Anderson BJ, Batchelor AS, Blackwell DD, DiPippo R, Drake EM, Garnish J, Livesay B, Moore MC, Nichols K, Petty S, Toksöz MN, Veatch RW Jr, Baria R, Augustine C, Murphy E, Negraru P, Richards M (2006) The Future of Geothermal Energy: impact of enhanced geothermal systems (EGS) on the United States in the $21^{\text {st }}$ century. MIT 
(Massachusetts Institute of Technology), Boston, http://www1.eere.energy.gov/geothermal/pdfs/ future_geo_energy.pdf. Accessed 11 May 2015

Van Wees J-D, Kronimus A, van Putten M, Pluymaekers MPD, Mijnlieff H, van Hooff P, Obdam A, Kramers L (2012) Geothermal aquifer performance assessment for direct heat production - Methodology and application to Rotliegend aquifers. Neth J Geosci 91:651-665

Wagner HW (1996) Bemerkungen zur Tektonik der Trier-Bitburger Mulde (SW-Deutschland). Schriftenr. Schiefer-Fachverb, Deutschl., Sonderband, pp 131-140

Wagner B, Dittrich D (2010) Profilschnitte A-A' bis F-F'. In: LGB \& LUWG (Landesamt für Geologie und Bergbau Rheinland-Pfalz \& Landesamt für Umwelt, Wasserwirtschaft und Gewerbeaufsicht Rheinland-Pfalz). LGB \& LUWG, Mainz

Wagner HW, Kremb-Wagner F, Koziol M, Negendank JFW (2012) Trier und Umgebung, 3rd edn. Gebr, Bornträger, Stuttgart

Walker KT, Bokelmann GHR, Klemperer SL, Bock G (2005) Shear-wave splitting around the Eifel hotspot: evidence for a mantle upwelling. Geophys J Int 163:962-980

Weidenfeller M, Löhr H, Weiler H (2004) Quartärgeologie, Hydrogeologie und Geoarchäologie in den Tälern von Mosel und unterer Saar (Exkursion G am 16. April 2004). Jber Mitt Oberrhein Geol Ver 86:203-235

Weiler H (1972) Ergebnisse von Bohrungen im Buntsandstein im Raume Trier-Bitburg. Mainzer geowiss Mitt 1:198-227

Weiler H (1991) Das Grundwasser in der Bitburger Trias-Mulde, Beschreibung eines Aquifers, neue Ergebnisse. Mainzer geowiss Mitt 20:9-42

Werle O (2009) Mineralwasser im Sauertal: die Quellen von Ralingen und Rosport. Jb Kreis Trier-Saarburg, 56-62

Wierich F (1999) Orogene Prozesse im Spiegel synorogener Sedimente; korngefügekundliche Liefergebietsanalyse siliziklastischer Sedimente im Devon des Rheinischen Schiefergebirges. Z Marburger Geowiss Vereinigung, vol 1. Marburger Geowiss Vereinigung, Marburg

Wildberger J (1992) Zur tektonischen Entwicklung des südwestlichen Hunsrücks (SW-Deutschland). Mitt Pollichia 79:5-119

Ziegler PA, Dèzes P (2007) Cenozoic uplift of Variscan Massifs in the Alpine foreland: timing and controlling mechanisms. Global Planet Change 58:237-269

Zimmermann G, Blöcher G, Reinicke A, Brandt W (2011) Rock specific hydraulic fracturing and matrix acidizing to enhance a geothermal system - concepts and field results. Tectonophysics 503:146-154

Zitzmann A, Grünig S (with contributions by Meyer W, Stets J, Mittmeyer H-G, Konrad HJ, Ribbert K-H, Fuchs G) (1987). Geologische Übersichtskarte 1:200000, Blatt CC 6302 Trier. BGR (Bundesanstalt für Geowissenschaften und Rohstoffe), Hannover

\section{Submit your manuscript to a SpringerOpen ${ }^{\circ}$} journal and benefit from:

- Convenient online submission

- Rigorous peer review

- Immediate publication on acceptance

- Open access: articles freely available online

- High visibility within the field

- Retaining the copyright to your article 